\title{
Tethered balloon-borne aerosol measurements: seasonal and vertical variations of aerosol constituents over Syowa Station, Antarctica
}

\author{
K. Hara ${ }^{1, *}$, K. Osada ${ }^{2}$, and T. Yamanouchi ${ }^{1}$ \\ ${ }^{1}$ National Institute of Polar Research, Tokyo, Japan \\ ${ }^{2}$ Graduate School of Environmental Studies, Nagoya University, Nagoya, Japan \\ * now at: Department of Earth System Science, Faculty of Science, Fukuoka University, Fukuoka, Japan
}

Correspondence to: K. Hara (harakei@fukuoka-u.ac.jp)

Received: 15 January 2013 - Published in Atmos. Chem. Phys. Discuss.: 26 March 2013

Revised: 6 June 2013 - Accepted: 28 July 2013 - Published: 10 September 2013

\begin{abstract}
Tethered balloon-borne aerosol measurements were conducted at Syowa Station, Antarctica, during the 46th Japanese Antarctic expedition (2005-2006). Direct aerosol sampling was operated from near the surface to the lower free troposphere (approximately $2500 \mathrm{~m}$ ) using a balloon-borne aerosol impactor. Individual aerosol particles were analyzed using a scanning electron microscope equipped with an energy dispersive X-ray spectrometer. Seasonal and vertical features of aerosol constituents and their mixing states were investigated. Results show that sulfate particles were predominant in the boundary layer and lower free troposphere in summer, whereas sea-salt particles were predominant during winter through spring. Minerals, $\mathrm{MgSO}_{4}$, and sulfate containing $\mathrm{K}$ were identified as minor aerosol constituents in both boundary layer and free troposphere over Syowa Station. Although sea-salt particles were predominant during winter through spring, the relative abundance of sulfate particles increased in the boundary layer when air masses fell from the free troposphere over the Antarctic coast and continent. Sea-salt particles were modified considerably through heterogeneous reactions with $\mathrm{SO}_{4}^{2-} \mathrm{CH}_{3} \mathrm{SO}_{3}^{-}$and their precursors during summer, and were modified slightly through heterogeneous reactions with $\mathrm{NO}_{3}^{-}$and its precursors. During winter through spring, sea-salt modification was insignificant, particularly in the cases of high relative abundance of sea-salt particles and higher number concentrations. In August, $\mathrm{NO}_{3}^{-}$and its precursors contributed greatly to sea-salt modification over Syowa Station. Because of the occurrence of sea-salt fractionation on sea ice, $\mathrm{Mg}$-rich sea-salt particles were identified during the months of April through November. In contrast, Mg-free sea-salt particles and slightly Mg-
\end{abstract}

rich sea-salt particles coexisted in the lower troposphere during summer. Thereby, Mg separation can proceed by sea-salt fractionation during summer in Antarctic regions.

\section{Introduction}

Atmospheric aerosol measurements have been made in Antarctic regions for several decades from numerous perspectives such as atmospheric material cycles, monitoring of Earth background levels, radiation budgets, and ice core record interpretation (e.g., Shaw, 1988; Ito, 1989, Legrand and Mayewski, 1997; Bromwich et al., 2012). Because of restrictions on logistics under severe conditions, most investigations of aerosol constituents were conducted at coastal stations such as Syowa Station, Neumayer Station, Halley Station, Dumont d'Urville Station, Mawson Station, and Aboa Station (e.g., Savoie et al., 1992, 1993; Teinilä et al., 2000; Legrand et al., 2001; Hara et al., 2004; Weller et al., 2011). Recently, aerosol measurements have been taken even at inland stations such as Amundsen-Scott (South Pole) Station, Dome F Station, Kohnen Station, and Concordia (Dome C) Station (e.g., Bodhaine, 1995; Hara et al., 2004; Jourdain et al., 2008; Weller and Wagenbach, 2007; Udisti et al., 2012).

Major aerosol constituents are $\mathrm{SO}_{4}^{2-}, \mathrm{CH}_{3} \mathrm{SO}_{3}^{-}, \mathrm{NO}_{3}^{-}$, sea salts(e.g., $\mathrm{Na}^{+}$and $\mathrm{Cl}^{-}$) in the Antarctic troposphere. Minor aerosol constituents are minerals and carbonaceous species (soot and organics). Particularly, $\mathrm{SO}_{4}^{2-}$ and $\mathrm{CH}_{3} \mathrm{SO}_{3}^{-}$are strongly predominan during summer (e.g., Minikin et al., 1998; Legrand et al., 2001). Size segregated aerosol analysis showed that $\mathrm{SO}_{4}^{2-}$ and $\mathrm{CH}_{3} \mathrm{SO}_{3}^{-}$were distributed mainly in 
the sub-micrometer range at the Antarctic coasts (e.g., Jourdain and Legrand, 2001; Read et al., 2008). Although the concentrations of $\mathrm{SO}_{4}^{2-}$ and $\mathrm{CH}_{3} \mathrm{SO}_{3}^{-}$reached maximum values in summer because of biogenic activity in the ocean (e.g., Minikin et al., 1998), high amounts of $\mathrm{SO}_{4}^{2-}$ and $\mathrm{CH}_{3} \mathrm{SO}_{3}^{-}$ were found during winter through spring at coastal stations (Minikin et al., 1998; Jourdain and Legrand, 2001; Preunkert et al., 2008; Read et al., 2008). In contrast to strong summer maxima of $\mathrm{SO}_{4}^{2-}$ and $\mathrm{CH}_{3} \mathrm{SO}_{3}^{-}$in aerosols (Minikin et al., 1998; Jourdain and Legrand, 2001; Preunkert et al., 2008; Read et al., 2008), the high concentrations of DMS and DMSO remained in winter at coastal and continental stations because of their longer lifetimes attributable to weak photochemical processes during winter (Jourdain and Legrand, 2001; Preunkert et al., 2008; Read et al., 2008). Particularly high concentrations of DMS and DMSO found at inland stations during winter implied considerable poleward transport to the interior of the continent.

Sea salts are predominant during winter through spring (e.g., Hara et al., 2004). Sea-salt particles were distributed widely in ultrafine-coarse modes throughout the year at Syowa Station (Hara et al., 2010a, 2011a) and were distributed in fine-coarse modes during summer at Aboa Station (Kerminen et al., 2000; Teinilä et al., 2000). Sea-salt particles can play important roles as scavengers of acidic species and as the origin of reactive halogen species through heterogeneous reactions in the Antarctic troposphere (e.g., Hara et al., 2004). Single particle analysis using an electron microscope equipped with an energy dispersive X-ray spectrometer suggested that sea-salt particles near the surface were modified with $\mathrm{SO}_{4}^{2-}$ and $\mathrm{CH}_{3} \mathrm{SO}_{3}^{-}$during summer, and were modified with $\mathrm{NO}_{3}^{-}$in August at Syowa Station (Mouri et al., 1999; Hara et al., 2005). Results obtained using other microprobe techniques such as laser microprobe mass spectrometry have implied that $\mathrm{SO}_{4}^{2-}$ and $\mathrm{CH}_{3} \mathrm{SO}_{3}^{-}$were mixed internally with sea-salt particles (Wouters et al., 1990; Hara et al., 1995). Furthermore, sea-salt particles in the free troposphere over Syowa Station were modified not only with $\mathrm{SO}_{4}^{2-}$ but also with $\mathrm{NO}_{3}^{-}$during summer (Hara et al., 2006). In addition to sea-salt modification, sea-salt particles were fractionated through precipitation of several salts such as mirabilite $\left(\mathrm{Na}_{2} \mathrm{SO}_{4} \quad 10 \mathrm{H}_{2} \mathrm{O}\right)$ and hydrohalite $\left(\mathrm{NaCl} 2 \mathrm{H}_{2} \mathrm{O}\right)$ in sea ice formation under colder conditions (e.g., Wagenbach et al., 1998; Hara et al., 2004, 2012). Concomitantly with the expansion of sea ice regions during winter through spring, the contributions of sea-salt particles derived from sea ice and frost flowers increased significantly (e.g., Wagenbach et al., 1998; Rankin et al., 2000, 2002; Hara et al., 2004, 2012). Fractionated sea-salt particles in coastal regions originate from sea ice and frost flowers (Wagenbach et al., 1998; Rankin et al., 2000, 2002; Hara et al., 2004, 2012). Therefore, sea-salt particles have been used as tracers (Hara et al., 2010a, 2011a) and as an index of sea ice extent (e.g., Wolff et al., 2006).
Regarded transport processes and material cycles, measurements of aerosol constituents such as black carbon and radionuclides have been conducted in Antarctic regions (Fiebig et al., 2009; Hara et al., 2010a; Elsässer et al., 2011). Continuous aerosol measurements at coastal stations suggest the substantial transport of combustion-origin aerosol particles from biomass burning in South America and southern Africa (Fiebig et al., 2009; Hara et al., 2010a, b). Our previous investigation (Hara et al., 2010a) revealed that longrange transport from biomass burning and mixing of seasalt particles cause aerosol-enhanced (haze) conditions at Syowa Station. The variety of radionuclides $\left({ }^{7} \mathrm{Be},{ }^{10} \mathrm{Be}\right.$ and ${ }^{210} \mathrm{~Pb}$ ) implied meridional transport to Antarctic coasts and mixing of stratospheric air into the troposphere (Elsässer et al., 2011). Previous investigations have provided important knowledge about aerosol chemical properties near the surface, such as concentrations, seasonal variations, and size distributions. Because of the dearth of knowledge of aerosol chemistry in the upper atmosphere, aerosol chemical properties and chemical processes have been discussed mainly based on results obtained from aerosol measurements near the surface. Recent ground-based aerosol measurements have revealed atmospheric processes that take place in the upper atmosphere: (1) accumulation of DMS and DMSO in the free troposphere and buffer layer (Legrand et al., 2001; Preunkert et al., 2008); (2) aerosol transport into inland areas through the free troposphere (Piel et al., 2006); (3) high abundance of volatile particles (e.g., sulfate particles) in the free troposphere during winter (Hara et al., 2011a); and (4) the likelihood of new particle formation (Koponen et al., 2003). Consequently, in situ aerosol measurements in the upper atmosphere are necessary for a better understanding of aerosol and other atmospheric processes in the Antarctic regions. Particularly direct aerosol sampling must be made in the boundary layer and free troposphere to elucidate atmospheric material cycles and atmospheric chemistry in the Antarctic troposphere.

Although airplanes, launched balloons and tethered balloons have been used to measure aerosols from the boundary layer to the free troposphere in Antarctic regions (Iwasaka et al., 1985; Ito et al., 1986; Yamazaki et al., 1989; Yamanouchi et al., 1999; Hayashi, 2001; Wada et al., 2001; Rankin and Wolff, 2002; Hara et al., 2006, 2011b; Osada et al., 2006; Kizu et al., 2010), direct aerosol sampling in the upper atmosphere has been conducted only for those aerosol measurements reported by Iwasaka et al. (1985), Yamazaki et al. (1989), Rankin and Wolff (2002), and Hara et al. (2006). These previous studies have revealed major aerosol constituents in the boundary layer and free troposphere and the likelihood of transport of sea-salt and mineral particles through the free troposphere. Tethered balloonborne and airplane-borne aerosol measurements (Osada et al., 2006; Hara et al., 2011b) have shown high concentrations of condensation nuclei $\left(\mathrm{CN}, D_{\mathrm{p}}>10 \mathrm{~nm}\right)$ by new particle formation in the lower free troposphere over Syowa 
Station. Because of operational limitations, seasonal features of vertical distributions of aerosol constituents in the upper atmosphere have not been understood. In this study, tethered balloon-borne aerosol measurements were performed to elucidate the vertical and seasonal features of aerosol constituents and their mixing states in the Antarctic troposphere. Herein, we mainly discuss (1) seasonal and vertical distributions of aerosol constituents, (2) sea-salt chemistry, and (3) vertical structures of Antarctic haze.

\section{Aerosol sampling and analysis}

Tethered balloon operations were conducted at the C-heliport of Syowa Station, Antarctica $\left(69^{\circ} 00^{\prime} \mathrm{S}, 39^{\circ} 35^{\prime} \mathrm{E}\right)$ on East Ongul Island, which is located in Lützow-Holm Bay and which lies ca. $4 \mathrm{~km}$ from the Prince Olav Coast of Antarctica. The distance from Syowa Station to the sea ice margin was approximately $100 \mathrm{~km}$ during summer and $1000 \mathrm{~km}$ from winter through spring. The C-heliport (ca. $15 \mathrm{~m}$ above sea level) is located at the windward side of prevailing winds and ca. $600 \mathrm{~m}$ from the main area, with its diesel power station. For safe operation, tethered-balloon-borne aerosol measurements were made under conditions with weaker surface winds (mean $<5 \mathrm{~m} \mathrm{~s}^{-1}$ ). In the case of strong winds $\left(>12 \mathrm{~m} \mathrm{~s}^{-1}\right.$ ) in the upper atmosphere, the balloon stopped ascending and then descended to avoid breakage of the tether line and balloon. When thick clouds appeared at observable altitudes over Syowa Station, the measurements stopped around the cloud base. In the case of thin clouds, aerosol measurements were continued above the clouds. Aerosol measurements and sampling were operated in the afternoon (LT) January-April and September-December and 10:4515:30 LT from May through August because safe operation required visible identification of the tethered balloon under light and dusk conditions.

A tethered balloon system (Vaisala) was used to obtain aerosol measurements in order to ascertain vertical features of aerosol number concentrations and aerosol constituents in the lower troposphere. Details of instruments for the tethered balloon-borne aerosol measurements are described by Hara et al. (2011b). Figure 1 depicts an example of the balloon trajectory during aerosol measurements. Measurements using a condensation particle counter (CPC), an optical particle counter (OPC), and aerosol sampling were conducted independently because of payload limitations. During the first flight, the aerosol number concentration and meteorological parameters were measured using CPC, OPC, and tethersonde. Second, direct aerosol sampling was conducted using an aerosol impactor and tethersonde.

A two-stage aerosol impactor developed by Okada et al. (1997) was customized by removal of the timer system and by addition of a radio-control system for the tethered balloon-borne aerosol sampling conducted for this study. The cut-off diameter of the impactor was $0.2 \mu \mathrm{m}$ and $2.0 \mu \mathrm{m}$ at a

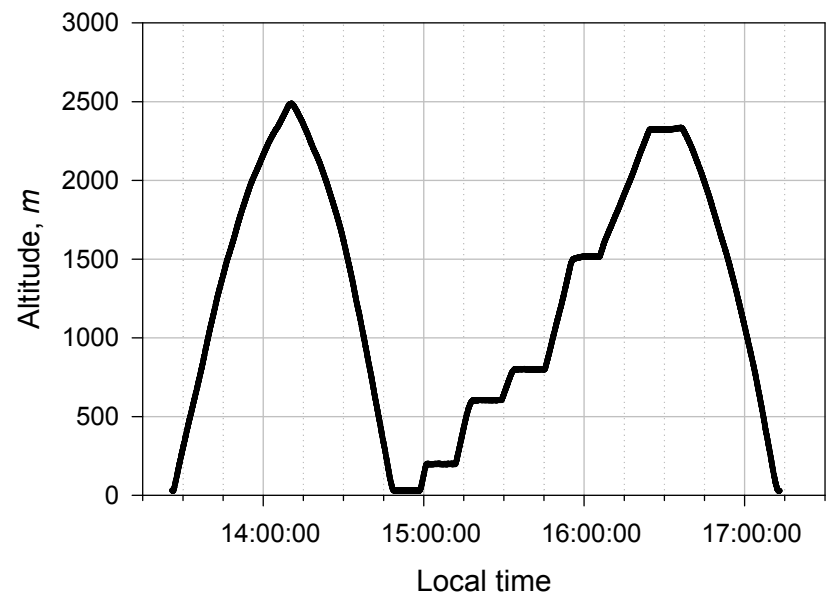

Fig. 1. Typical balloon trajectory (14 March 2005).

flow rate of $1.2 \mathrm{~L} \mathrm{~min}^{-1}$. During the second flight, aerosol samples taken at 3-5 levels (depending on the highest altitude of the first flight) were chosen based on vertical profiles of air temperature and relative humidity. The altitude was maintained during aerosol sampling. Each aerosol sampling required $10-15 \mathrm{~min}$, as shown in Fig. 1. The aerosol impactor was controlled manually by radio commands from the ground. Aerosol particles were collected on the carboncoated collodion thin film supported by Ni-TEM grid. Unfortunately, aerosol samples were not taken on 6 and 15 January, or 1 August because of mechanical trouble that occurred with the impactor and the tethered balloon system.

After aerosol measurements and sampling, aerosol samples were kept in polyethylene capsules. To avoid contamination, aerosol samples were handled under clean air flow of a clean bench. The polyethylene capsules with aerosol samples were packed into polyethylene bags, each of which had a zipper. All bags with aerosol samples were put into an airtight box together with a desiccant (Nisso-Dry M; Nisso Jushi Co. Ltd.) until analysis to prevent humidification that can engender morphology change and efficient chemical reactions. We used scanning electron microscopy - energy dispersive Xray spectrometry (SEM-EDX, Quanta FEG-200F; FEI Co., and XL30; EDAX Inc.) for elemental analyses of single particles. To avoid analytical bias of localization of aerosol constituents in each particle, the rectangular or square area almost covering a particle was scanned using an electron beam in EDX analysis. Procedures and conditions of singleparticle analysis were in accordance with those described by Hara et al. (2002, 2005). Generally, the detection limit of EDX analysis is $0.1-1 \%$, depending on analytical conditions, elemental compositions, and particle morphology. We analyzed artificial particles (such as $\mathrm{NaCl}, \mathrm{Na}_{2} \mathrm{SO}_{4}$ and their mixtures) with the size range of $0.2-6 \mu \mathrm{m}$ to verify their analytical quality. In our analytical conditions (e.g., counting time of $30 \mathrm{~s}$ ), relative error from counting statics was a few percent, even in sub-micrometer particles for all elements 
Relative humidity, \%

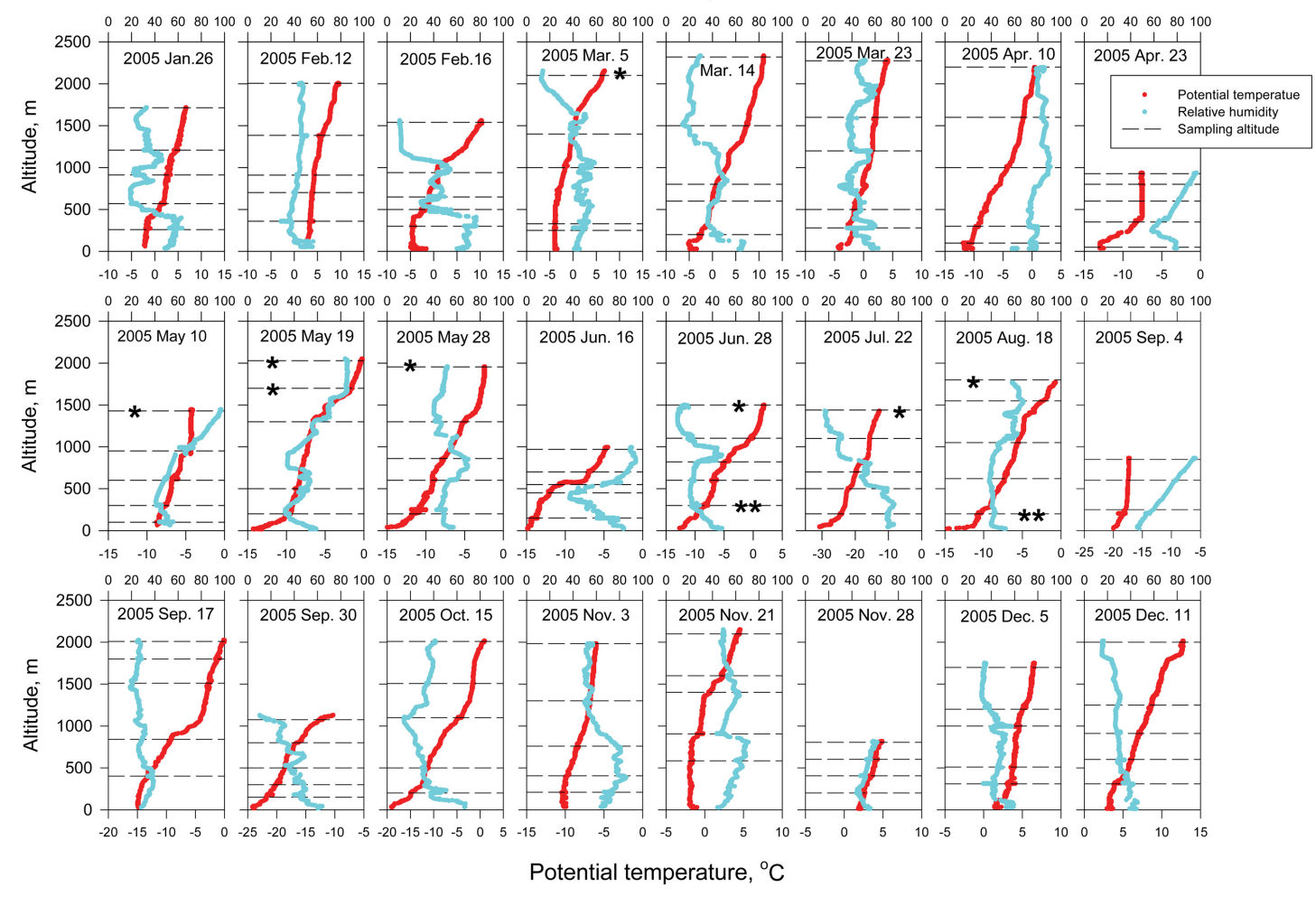

Fig. 2. Vertical profiles of potential temperature and relative humidity during the second flight. Red and blue lines respectively show potential temperature and relative humidity. Dashed lines represent altitudes of aerosol sampling. Single and double asterisk marks respectively show "sampling failed by trouble with radio communication" and "sample disabled by damage to thin film".

heavier than Na. Analytical deviation in elements heavier than $\mathrm{Na}$ was estimated as \pm several percent in the range of sub-micrometer-super-micrometer in this study. The deviation tended to be smaller for larger particles. These values were closely coincident with results reported by Laskin and Cowin (2001). We analyzed 37533 particles in fine mode $\left(D_{\mathrm{p}}: 0.2-2.0 \mu \mathrm{m}\right)$ and 2095 particles in coarse mode $\left(D_{\mathrm{p}}\right.$ $>2.0 \mu \mathrm{m})$ in this study. Because of the lower number density, none to several particles were analyzed in some samples in coarse mode.

\section{Results and discussion}

\subsection{Meteorological conditions during aerosol sampling}

Figure 2 depicts vertical profiles of potential temperature and relative humidity in the direct sampling flight. A surface inversion layer was identified in many cases (particularly winter-spring). The surface inversion layer height was $<100$ to ca. $350 \mathrm{~m}$. The altitude of the boundary layer top was approximately $500-1200 \mathrm{~m}$, as inferred from comparison of vertical features of potential temperature, relative humidity, and aerosol number density (Hara et al., 2011a). As shown in Fig. 2, direct aerosol sampling was conducted in the surface inversion layer, boundary layer, and free troposphere. Unfortunately, few aerosol samples were taken at the highest altitudes ( $>1400 \mathrm{~m}$ ) during May through August because of radio communication trouble.

\subsection{Backward trajectory from the sampling altitudes}

Figure 3 depicts examples of 5-day backward trajectory from the altitudes of aerosol sampling over Syowa Station. The trajectory was computed using vertical motion mode in the NOAA-HYSPLIT model with the "NCEP reanalysis" dataset (Draxler and Rolph, 2013). The air mass history in this study was classified into four types, as shown in Fig. 3. On 26 January (Fig. 3a), air masses were transported westward along the coastline. According to Suzuki et al. (2004), this pathway was dominant at Syowa Station during summer. On 5 March (Fig. 3b), air masses in the boundary layer came from the free troposphere over the interior of the continent. Furthermore, air masses were transported downward along the continental surface. This transport path might have resulted from effects of katabatic wind. In contrast, air masses in the free troposphere came eastward from the free troposphere over the coast and Southern Ocean. On 28 May (Fig. 3c), air masses in the boundary layer and free troposphere were transported from the Southern Ocean. In addition, air parcels were lifted 

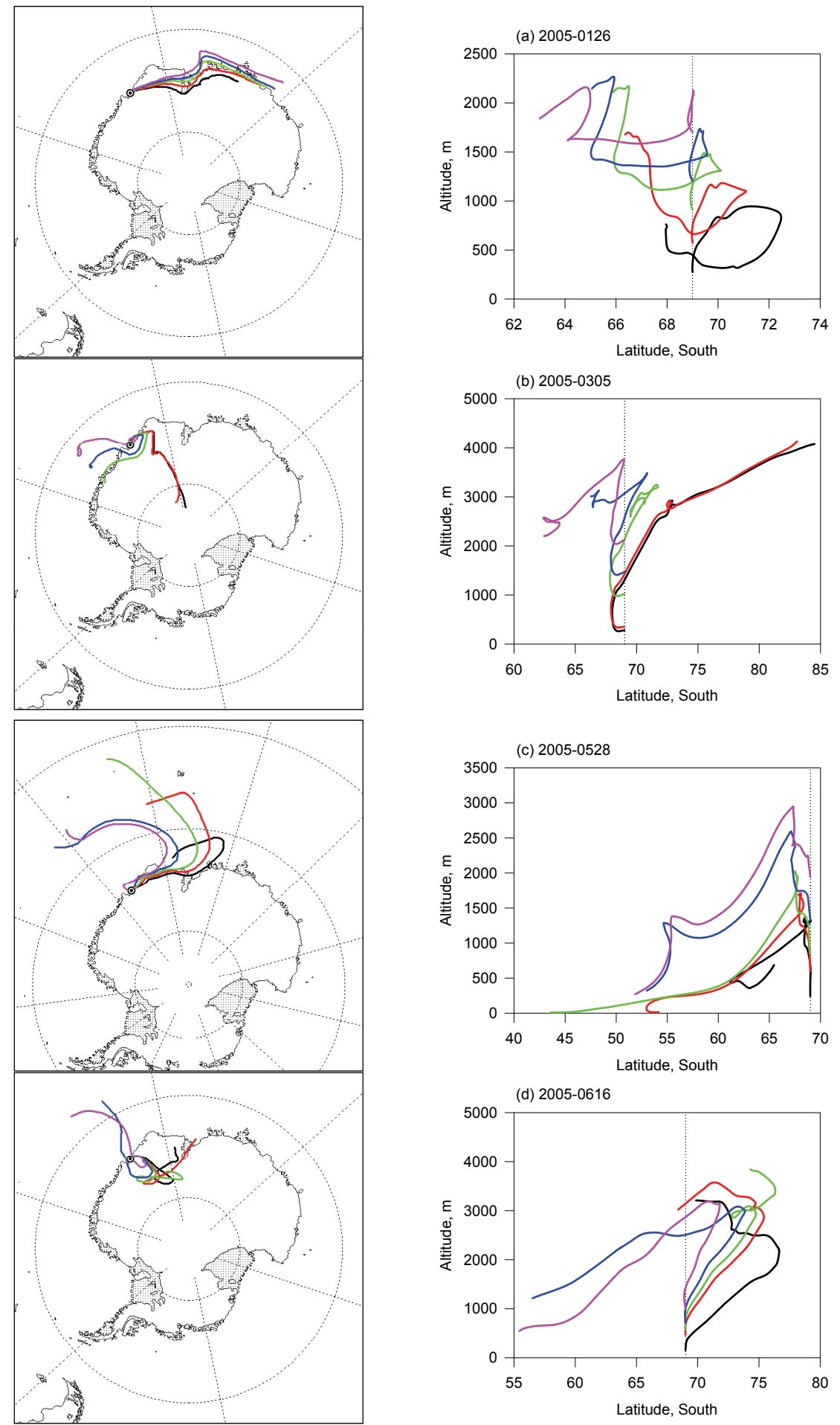

Fig. 3. Typical 5-day backward trajectories: (a) on 26 January, (b) 5 March, (c) 28 May, and (d) 16 June. Dashed lines in right panels show the Syowa Station latitude.

from the boundary layer to the free troposphere. This flow pattern was associated with the approach of a cyclone, as explained by Hara et al. (2010a). On 16 June (Fig. 3d), air masses in the boundary layer were transported from the inte- rior of the continent, similar to the case on 5 March, whereas air masses in the free troposphere came from the Southern Ocean. This transport pathway was consistent with vertical features of potential temperature and relative humidity 

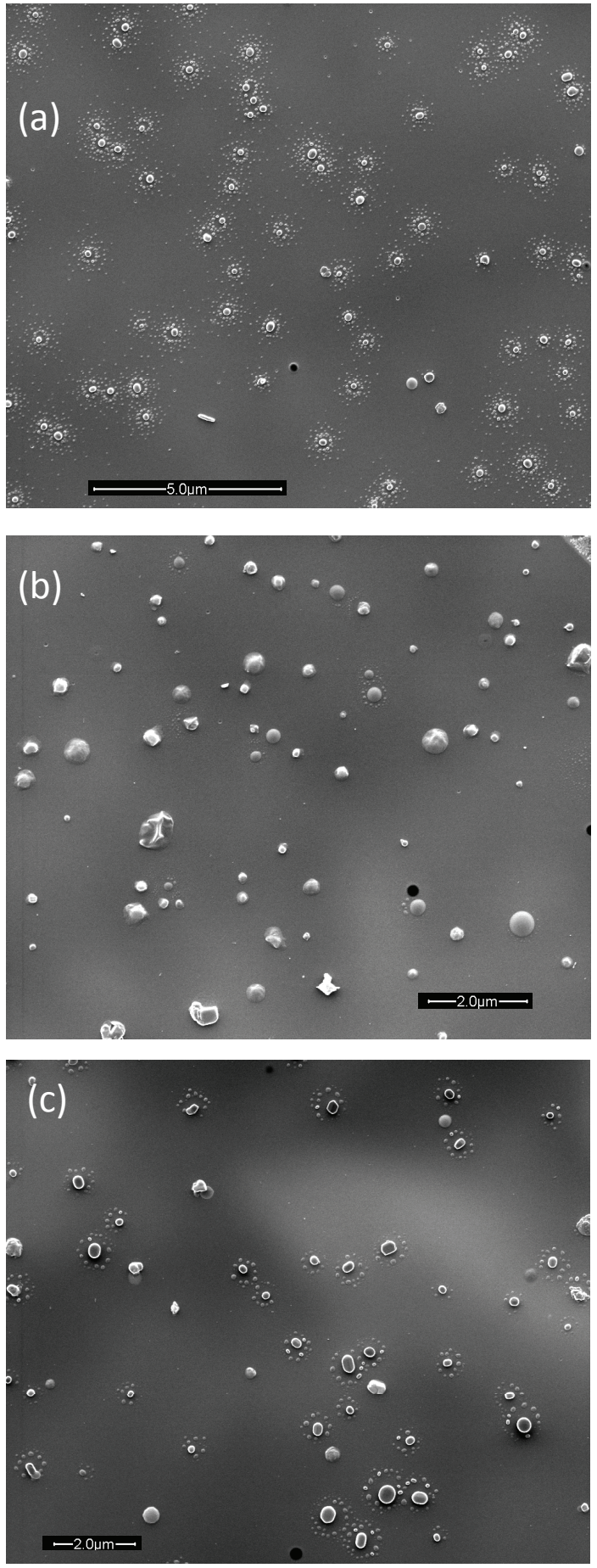

Fig. 4. Typical SEM images of aerosol particles collected (a) at $1245 \mathrm{~m}$ on 11 December, (b) at $498 \mathrm{~m}$ on 22 July, and (c) at $145 \mathrm{~m}$ on 16 June.
(Fig. 2). All backward trajectories are presented in the Supplement.

\subsection{Aerosol constituents collected in the lower troposphere over Syowa Station}

Figure 4 presents examples of SEM images of aerosol particles collected in the tethered-balloon-borne aerosol sampling. Most aerosol particles exhibited the satellite structure shown in Fig. 4a. This unique morphology was observed predominantly in the Antarctic troposphere (Yamato et al., 1987; Hara et al., 2006). Several particles have no satellite structure in Fig. 4a. In contrast to the predominance of satellite particles in summer, aerosol particles with solid materials and without a satellite structure were predominant during winter through spring, as shown in Fig. 4b. Although aerosol particle without a satellite structure were usually predominant during winter through spring in this study, the number density of aerosol particles with a satellite structure increased occasionally in the lower boundary layer during winter through spring, as shown in Fig. 4c.

Figure 5 depicts examples of EDX spectra of aerosol particles collected over Syowa Station. In this study, carboncoated collodion thin film on the Ni-grid was used as the sample substrate, so that strong background peaks of $\mathrm{C}, \mathrm{O}$, and $\mathrm{Ni}$ were obtained in EDX analysis. These elements were excluded from discussion. In addition, the strong carbon peak hampers identification and determination of $\mathrm{N}$ in EDX analysis. In Fig. 5a, $\mathrm{Na}, \mathrm{Mg}, \mathrm{S}, \mathrm{Cl}, \mathrm{K}$, and $\mathrm{Ca}$ were detected from aerosol particle. Because the atomic ratio of these elements was close to the atomic ratio in seawater, this particle might be identified as sea-salt particles with less sea-salt modification. Although aerosol particle in Fig. 5b had similar constituents to particles in Fig. 5a, the relative peak height of $\mathrm{Mg}$ to Na was higher than that in seawater and sea-salt particle in Fig. 5a. These particles might be identified as Mg-enriched sea-salt particles. $\mathrm{Mg}$-enrichment in sea-salt particles was observed in winter through spring at Syowa Station, Antarctica (Hara et al., 2005, 2010a). In contrast, Mg-poor sea-salt particles were also observed in this study (not shown). Details of sea-salt fractionation are discussed later (Sects. 3-7). Major elements of aerosol particle in Fig. 5c were $\mathrm{Na}$ and $\mathrm{S} . \mathrm{Cl}^{-}$in sea-salt particles can be depleted through heterogeneous reactions with acidic species during summer, as explained by Mouri et al. (1999) and Hara et al. (2005). Therefore, the particle in Fig. $5 \mathrm{c}$ are identifiable as wholly $\mathrm{Cl}^{-}$ depleted sea-salt particles modified by acidic sulfur species such as $\mathrm{SO}_{4}^{2-}$ and $\mathrm{CH}_{3} \mathrm{SO}_{3}^{-}$. Hereinafter, we designate particles of this type as "modified sea-salt particles". Aerosol particle in Fig. 5d contained $\mathrm{Na}, \mathrm{Cl}$, and K. Unlike sea-salt and modified sea-salt particles in Fig. 5a-c, the atomic ratios of $\mathrm{Cl}$ and $\mathrm{K}$ were higher than the seawater ratio. A K-Cl rich particle was obtained only once in an aerosol sample in coarse mode collected at $615 \mathrm{~m}$ on 10 May 2005 . 

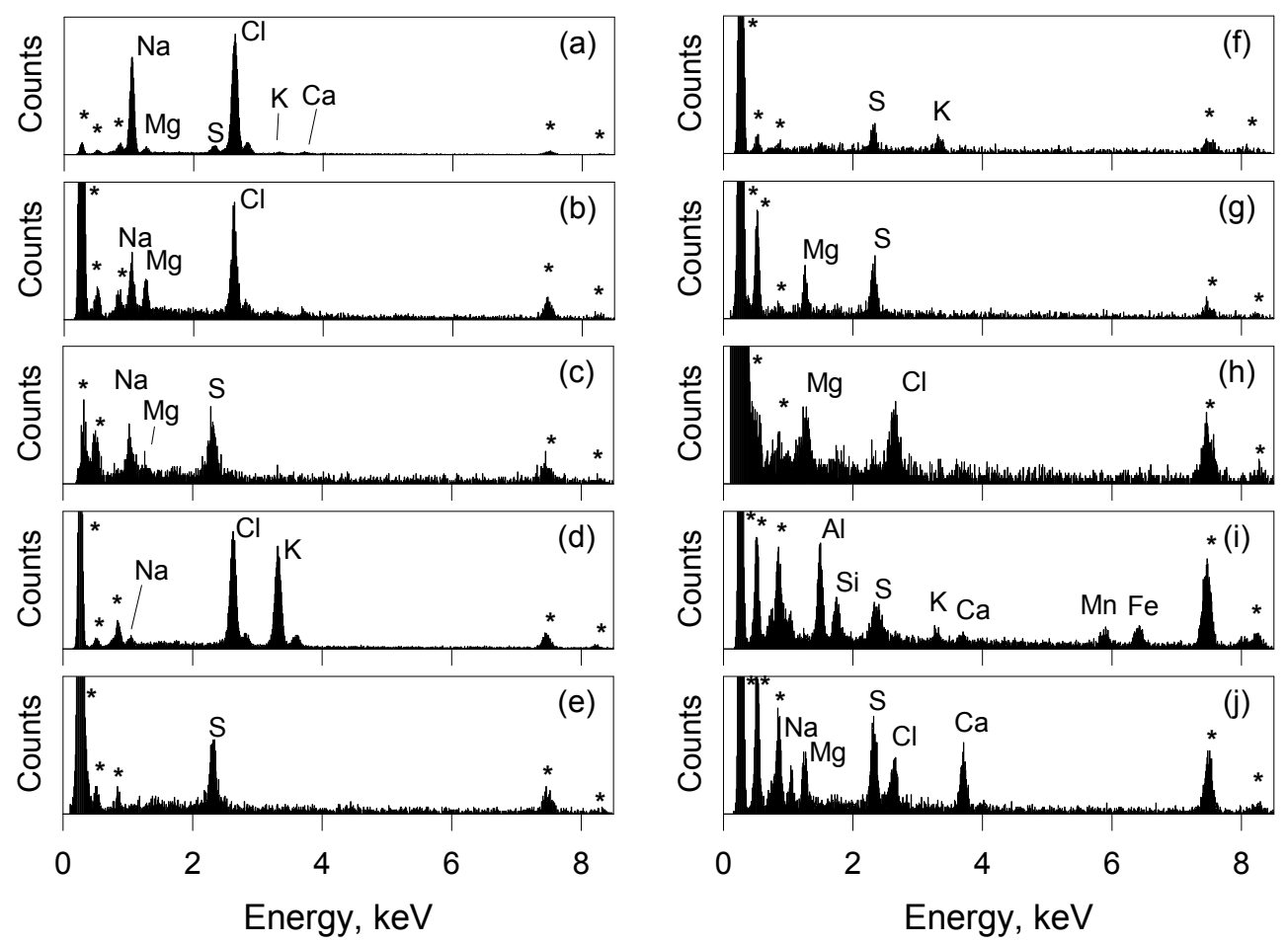

Fig. 5. Typical EDX spectra of aerosol particles collected over Syowa Station. Asterisks denote background peaks from the sample substrate. Aerosol particles were sampled (a) at $100 \mathrm{~m}$ on 10 April in fine mode, (b) at $200 \mathrm{~m}$ on 22 July in coarse mode, (c) at $310 \mathrm{~m}$ on 5 December in fine mode, (d) at $600 \mathrm{~m}$ on 10 May in coarse mode, (e) at $910 \mathrm{~m}$ on 12 February in fine mode, (f) at $850 \mathrm{~m}$ on 4 September in fine mode, (g) at $310 \mathrm{~m}$ on 11 December in fine mode, (h) at $1100 \mathrm{~m}$ on 15 October in coarse mode, (i) at $150 \mathrm{~m}$ on 16 June in coarse mode, and (j) at $50 \mathrm{~m}$ on 23 April in coarse mode.

Aerosol particle in Fig. 5e consist of S. In addition, aerosol particles containing only $\mathrm{S}$ (as shown in Fig. 5e) had a satellite structure on the substrates. These particles might be sulfate particles. According to previous works using chemical tests (Yamato et al., 1987) and laser microprobe techniques (Hara et al., 1995), sulfate particles in the Antarctic troposphere were composed predominantly of $\mathrm{H}_{2} \mathrm{SO}_{4}$ and were mixed internally with $\mathrm{CH}_{3} \mathrm{SO}_{3}^{-}$. Consequently, major components of the particle in Fig. 5e might be acidic sulfates related to ocean bioactivity. Because EDX can provide only elemental information, mixing states of $\mathrm{SO}_{4}^{2-}$ and $\mathrm{CH}_{3} \mathrm{SO}_{3}^{-}$ were not identified in this study. Hereinafter, we designate particles of this type as "sulfate particles". Aerosol particle in Fig. $5 f$ contained $\mathrm{S}$ and $\mathrm{K}$. These particles might be sulfates containing K. In contrast to "sulfate particles", sulfate particles containing $\mathrm{K}$ showed no satellite structure. Although sulfate particles in the Antarctic troposphere were derived predominantly from bioactivity in the ocean during summer (e.g., Minikin et al., 1998), sulfate containing K cannot be released from oceanic bioactivity and cannot be formed by new particle formation and gas-to-particle conversion from aerosol precursors. Okada et al. $(2001,2008)$ reported that sulfates containing $\mathrm{K}$ are present even in the free troposphere in the Southern Hemisphere and that they were released from combustion sources such as biomass burning. Indeed, aerosol particles from biomass burning in South America and southern Africa can be transported to coastal Antarctica (Fiebig et al., 2009; Hara et al., 2010a). Consequently, aerosol particle depicted in Fig. $5 \mathrm{f}$ might be particles of combustion origin. As shown in Fig. $5 \mathrm{~g}, \mathrm{Mg}$ and $\mathrm{S}$ were detected using EDX analysis. Atomic ratios of $\mathrm{Mg}$ and $\mathrm{S}$ were $52 \%$ and $48 \%$, respectively, in Fig. 5g; the particle might be composed predominantly of $\mathrm{MgSO}_{4}$. $\mathrm{Mg}$ and $\mathrm{Cl}$ were detected from the aerosol particle in Fig. 5h. These particles were observed once in fine mode on 30 September. From the atomic ratio of $\mathrm{Mg}$ and $\mathrm{Cl}$, the particles were inferred as $\mathrm{MgCl}_{2}$. The aerosol particle in Fig. 5i contained $\mathrm{Al}, \mathrm{Si}, \mathrm{S}, \mathrm{K}, \mathrm{Ca}, \mathrm{Mn}$, and $\mathrm{Fe}$. Because staining of aqueous solution was observed clearly around the solid particles in SEM image, these particles might be mineral particles coated by sulfates. In Fig. 5j, $\mathrm{Na}, \mathrm{Mg}, \mathrm{S}, \mathrm{Cl}$, and $\mathrm{Ca}$ were detected in EDX analysis. These particles might be an internal mixture of sea salt (or $\mathrm{Mg}$ enriched sea salt) and $\mathrm{CaSO}_{4}$.

Modified sea-salt particles, Mg-rich sea-salt particles, $\mathrm{Mg}$-poor sea-salt particles, Mg-rich sulfates, and $\mathrm{MgCl}_{2}$ were identified in this study. We first attempt to discuss the likelihood that these particles were derived from postsampling modification/fractionation processes or not. If the 
post-sampling processes proceed, then plausible processes are (1) phase transformation under storage (until analysis), (2) particle separation under lower relative humidity and high-vacuum conditions, and (3) particle separation by electron beam radiation. Aerosol samples were kept under conditions with airtight and relative humidity lower than 5-10\% until analysis. Because of airtight and dry conditions, sea-salt modification proceeds only slightly during sample storage. Additionally, dry conditions did not lead to a phase transformation, so that aerosol separation and fractionation cannot occur. In SEM-EDX analysis, aerosol particles were exposed to high-vacuum conditions (ultimately dry condition). Particle separation, however, occurs only slightly, although dry conditions can engender deliquescence and localization of aerosol constituents in each particle. Particle separation by electron beam radiation was not observed in SEM-EDX analysis. In addition, these particles have stains or satellite structures around the particles, as shown in Fig. 4. These structures might be formed by impaction on sample substrates during aerosol sampling. In this study, aerosol particles were almost covered with analytical spots to prevent analytical artifacts by localization of aerosol constituents in each particle. Furthermore, the analytical depth in our analytical condition was sufficiently large to detect characteristic X-rays from inside the aerosol particles on substrates. Therefore, analytical bias might not be important for this study. We concluded that modified sea-salt particles, Mg-rich sea-salt particles, $\mathrm{Mg}$ free sea-salt particles, $\mathrm{Mg}$-rich sulfates, and $\mathrm{MgCl}_{2}$ were not derived from post-sampling modification/fractionation processes and analytical bias. They were present in the ambient atmosphere.

Single particle analysis of aerosol particles collected in the Arctic troposphere revealed that major aerosol constituents in spring and summer were sulfates and that minor constituents were sea salts, soot, and minerals (Ishizaka et al., 1989; Hara et al., 2003, 2010c; Warneke et al., 2010). Compared to the Antarctic atmosphere, higher relative abundance of soot and soot-bearing particles was obtained in the Arctic troposphere (e.g., Hara et al., 2003, 2010c). Because SEM-EDX analysis was unable to observe internal mixing states of soot, internal mixing states of soot were not identified in this study. Regarding our analyzed and observed aerosol samples, external mixtures of soot particles were not obtained in this study. Lower relative abundance of soot particles in the Antarctic troposphere suggests strongly that anthropogenic and combustion processes make no important contribution to aerosol particles in the Antarctic troposphere.

\subsection{Vertical and seasonal features of aerosol constituents over Syowa Station}

Aerosol particles of several types were identified in this study, as shown in Fig. 5. The following sections present seasonal features and vertical features of aerosol constituents (sea-salt particles, aerosol particles containing sulfates, and mineral particles). For quantitative discussion, the relative abundance was estimated from the results of EDX analyses, as shown in Fig. 6.

\subsubsection{Sea-salt particles}

In coarse mode, sea-salt particles were predominant in the lower troposphere throughout the year. Modified sea-salt particles in coarse mode were observed mainly during summer. Additionally, Cl-depletion from sea-salt particles containing $\mathrm{Cl}$ proceeded partly during summer (details are presented in Sects. 3.6). Compared to sea-salt particles in coarse mode, the relative abundance of sea-salt particles and modified seasalt particles in fine mode was $<2-12.5 \%$ in the boundary layer from summer through autumn (January-mid-March and November-December). In the lower free troposphere during summer, sea-salt particles or modified sea-salt particles in fine mode were occasionally not observed in some samples. Moreover, the modified sea-salt particles were predominant in fine mode in January through mid-March and November-December.

During winter through spring, sea-salt particles were strongly predominant in coarse mode in both the boundary layer and lower free troposphere. The relative abundance of sea-salt particles increased gradually in fine mode from midMarch, and the relative abundance of the modified sea-salt particles decreased. Sea-salt particles (containing $\mathrm{Cl}$ ) were the most abundant aerosol constituents during winter (abundance, ca. $90 \%$ ) in the boundary layer and lower free troposphere, although low abundance of sea-salt particles was occasionally observed in winter (e.g., 19 May, 16 June, and 28 June), as shown in Fig. 4c. Earlier near-surface investigations at Syowa Station (Hara et al., 2004, 2010a, 2011a) and at Neumayer Station (Weller et al., 2011) revealed a predominance of sea-salt particles and high abundance of nonvolatile particles (probably sea-salt particles) during winter through spring. Sea-salt particles were predominant in the free troposphere during winter on 28 May and 28 July. Seasalt particles might be lifted up to the free troposphere under storm conditions by frequent cyclone approaches during winter through spring. Because of occasional failure of aerosol sampling at the highest altitudes (free troposphere), however, vertical features of the sea-salt particles in the free troposphere during winter were uncertain.

\subsubsection{Aerosol particles containing sulfates}

High abundance of sulfate particles in coarse mode was observed in the boundary layer and lower free troposphere during summer through autumn. Particularly, sulfate particles in coarse mode were predominant in the lower free troposphere during summer (26 January, 16 February, 5 March, 5 December, and 11 December). The relative abundance of sulfate particles in fine mode mostly exceeded $90 \%$ in both the boundary layer and free troposphere during summer. The sulfate 


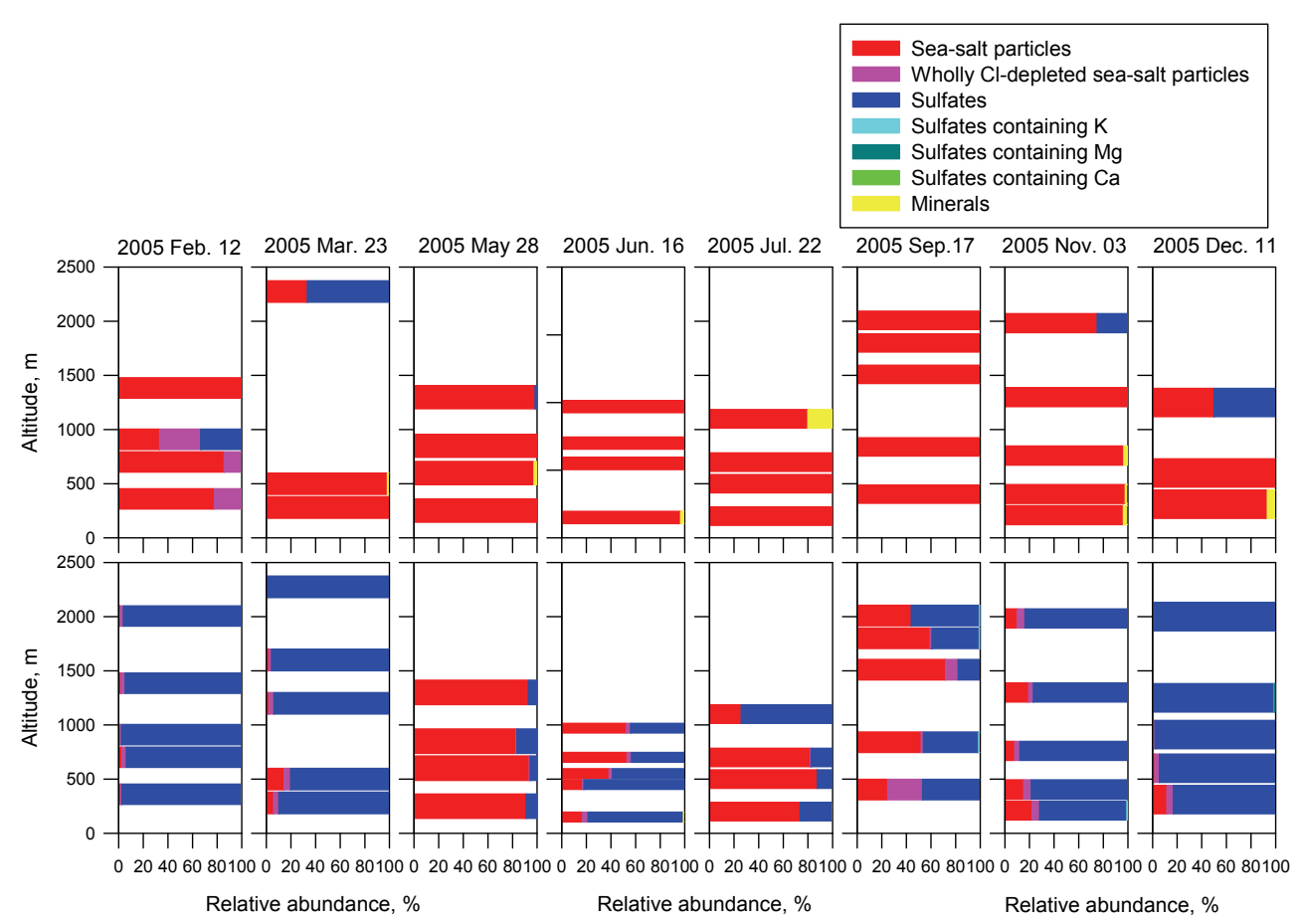

Fig. 6. Typical vertical features of relative abundance of aerosol constituents in coarse and fine modes in the lower troposphere. Upper and lower panels respectively show vertical features in coarse particles and fine particles. All plots are listed in the Supplement.

particle predominance persisted until the end of March, when the relative abundance of sea-salt particles and modified seasalt particles increased. Thereafter, the abundance of sulfate particles increased again in October, and reached $>95 \%$ by the end of November in both the boundary layer and free troposphere. Considering that the $\mathrm{CN}$ enhanced layer was observed often during summer (Hara et al., 2011b), condensable vapors such as gaseous $\mathrm{H}_{2} \mathrm{SO}_{4}$ and $\mathrm{CH}_{3} \mathrm{SO}_{3} \mathrm{H}$ might be enhanced in the free troposphere. Indeed, DMS oxidation and accumulation in the free troposphere and buffer layer were reported by Legrand et al. (2001) and by Preunkert et al. (2008). The concentrations of aerosol precursors might increase to enable new particle formation in the free troposphere, with subsequent particle growth through condensation of the condensable vapors and coagulation during transport.

Although sea-salt particles and modified sea-salt particles were usually predominant during winter, higher abundance of sulfate particles (approximately $80 \%$; some examples are 19 May, and 16 and 28 June, 2005) in the boundary layer during winter. Particularly high abundance of sulfate particles in winter was obtained in the surface inversion layer and lower boundary layer. Details of higher relative abundance of sulfate particles during winter through spring are discussed later in Sect. 3.5.2.

K-rich sulfate particles were distributed mostly in fine mode, except in March through May, July, and October, and were identified in the boundary layer and free troposphere in this study. Relative abundance of K-rich sulfate particles in fine mode ranged from "not-detected" to $2.4 \%(<1 \%$ in most cases). With the exception of January-February, seasons with identification of K-rich sulfate particles corresponded well to seasons with high abundance of plume outflow from South America and southern Africa (Hara et al., 2010a). Consequently, K-rich sulfate particles over Syowa Station might be supplied by long-range transport from combustion processes in middle and lower latitudes such as South America and southern Africa. In spite of low abundance of plume outflow, K-rich sulfate particles were identified even in January and February in this study. Backward trajectory (see the Supplement) showed that air masses containing Krich sulfate particles in January and December came from the free troposphere over the Antarctic continent without significant combustion sources. Previous model studies (Koch and Hansen, 2005; Stohl and Sodemann, 2010) elucidated transport from low latitudes and middle latitudes to Antarctic regions through the upper free troposphere. Considering the high BC concentration at the South Pole in summer (Bodhaine, 1995), we must discuss the likelihood of transport of combustion-origin aerosols through the upper troposphere during the summer season.

Mg-rich sulfate $\left(\mathrm{MgSO}_{4}\right)$ particles were distributed only in fine mode in this study. Relative abundance of $\mathrm{Mg}$ rich sulfate particles ranged from "not detected" to $1.9 \%$. Mg-rich sulfate particles were identified in samples obtained during January through mid-May, 4 September and 
October-December, so that variations of Mg-rich sulfates might have strong seasonality along the Antarctic coasts. In addition, Mg-rich sulfate particles were observed predominantly in samples taken in the boundary layer. Analysis of backward trajectories (see the Supplement) showed that air masses containing $\mathrm{Mg}$-rich sulfate particles were transported over the Antarctic continent and coastal areas in most cases. A similar transport pathway, however, was observed in air masses without $\mathrm{Mg}$-rich sulfates during winter, which implies that the presence of Mg-rich sulfate particles might be associated not only with the transport pathway but also with seasonal features of the origin of Mg-rich sulfates. To our knowledge, no report in the literature describes identification of Mg-rich sulfate particles in aerosol particles in the Antarctic troposphere, although $\mathrm{MgSO}_{4}$ microparticles and $\mathrm{Mg}$-rich particles were obtained in ice cores and surface snow taken in the Antarctic plateau (Ohno et al., 2005; Iizuka et al., 2006, 2012). Therefore, $\mathrm{Mg}$-rich sulfate particles might not originate from sea-salt fractionation on sea ice during winter through spring but from other sources during summer. Details of sea-salt fractionation and origins of $\mathrm{Mg}$-rich particles are discussed in Sects. 3.7.

\subsubsection{Mineral particles}

Mineral particles in coarse and fine modes were identified in the boundary layer and lower free troposphere throughout the year. The relative abundance of aerosol particles containing minerals ranged from not-detected to approximately $50 \%$ in coarse mode, and from not-detected to approximately $4 \%$ in fine mode. A dry soil surface appeared partly in the Ongul Islands from the end of December to early February. Therefore, mineral particles in the boundary layer might be affected by local emissions in addition to long-range transport. Local emission of mineral particles, however, can be negligible from the end of February to early December because the soil surface is covered with snow. According to Wagenbach (1996) and Weller et al. (2008), seasonal variations of mineral particles showed maximum values in the summer season at Neumayer Station. Previous investigations revealed that the cyclonic system engenders long-range transport of mineral particles to the Antarctic coasts (Pereira et al., 2004; Hara et al., 2010a; Li et al., 2010). Considering the presence of mineral particles in the boundary layer and the free troposphere found in this study and in previous investigations (Pereira et al., 2004; Hara et al., 2006, 2010a; Weller et al., 2008; Li et al., 2010), mineral particles might be supplied by long-range transport to Syowa Station through the boundary layer and free troposphere.

\subsection{Relation between transport processes and vertical features of aerosol constituents}

As described above, vertical features of aerosol constituents in the winter through spring seasons are likely to be associ- ated with the air mass history. In this section, we specifically examine the relation between air mass history and a predominance of sea-salt particles and sulfate particles in the lower troposphere during the winter through spring seasons.

\subsubsection{Predominance of sea-salt particles in the lower troposphere}

High relative abundance of sea-salt particles was observed in the lower troposphere during winter through spring, particularly on 28 May, 22 July, and 4 September, when the aerosol number concentrations were enhanced in the boundary layer and lower troposphere (Hara et al., 2011b). For instance, air parcels at sampling altitudes on 28 May came from the boundary layer $(<500 \mathrm{~m})$ at $51-60^{\circ} \mathrm{S}$ (as shown in Fig. 3c), which is over the ocean in a sea ice area. This poleward pathway was associated with the approach of a cyclone, which passed north of Syowa Station before the tethered balloon observation on 28 May 2005. With poleward flow and vertical mixing, sea-salt particles might be distributed in the lower free troposphere in the case of 28 May. Furthermore, remarkable aerosol enhancement (Antarctic haze) was observed near the surface at Syowa Station 24-27 May 2005 (Hara et al., 2010a). Although the aerosol number concentrations of $D_{\mathrm{p}}>0.3 \mu \mathrm{m}$ were approximately $5000 \mathrm{~L}^{-1}$ in the boundary layer on 28 May, the number concentrations reached $20258 \mathrm{~L}^{-1}$ at $1300 \mathrm{~m}$ (Hara et al., 2011b). Consequently, the aerosol-enhanced condition (Antarctic haze) persisted in the lower free troposphere on 28 May. Aerosol enhancement by vertical mixing was obtained over Syowa Station immediately after the cyclone's passing (Yamanouchi et al., 1999). Similar to the Antarctic haze condition near the surface (Hara et al., 2010a), sea-salt particles were major constituents in the aerosol enhanced layer in the case of 28 May, as depicted in Fig. 6.

Similar to the cases on 28 May, high relative abundance of sea-salt particles and high aerosol number concentrations were observed in the boundary layer on 22 July and 4 September. Air masses were transported from the boundary layer over sea ice and over the Southern Ocean (see the Supplement). Similar to the case on 28 May, strong winds were observed at Syowa Station by the cyclone approach before aerosol enhanced conditions and sea-salt particle predominance. Therefore, strong wind conditions attributable to the cyclone approach might engender a significant release of sea-salt particles from surface of sea ice and ocean by windblowing processes, as suggested by Hara et al. (2010). Because strong winds were observed usually at Syowa Station from winter through spring (Sato and Hirasawa, 2007), high abundance of sea-salt particles might be typical in the boundary layer, as described by Hara et al. (2004, 2010a, 2011a) and Weller et al. (2011). 


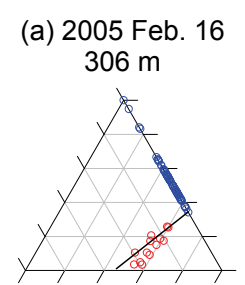

(b) 2005 Mar. 23 $500 \mathrm{~m}$

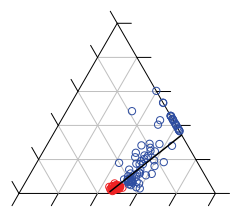

(f) 2005 Sep. 4 $625 \mathrm{~m}$

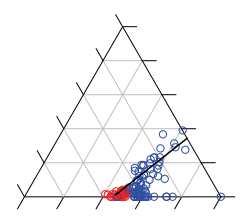

(g) 2005 Nov. 3 $408 \mathrm{~m}$

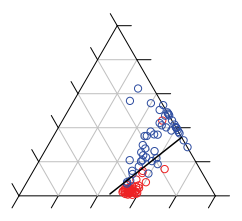

(c) 2005 Apr. 23

$47 \mathrm{~m}$

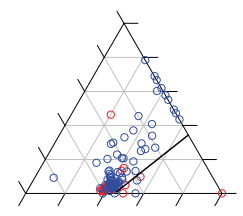

(h) 2005 Nov. 21 $585 \mathrm{~m}$

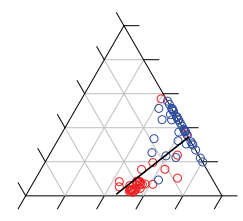

(d) 2005 May 28

$605 \mathrm{~m}$

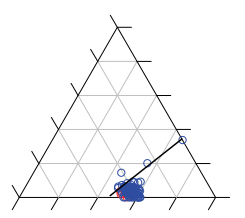

(i) 2005 Dec. 11 $330 \mathrm{~m}$

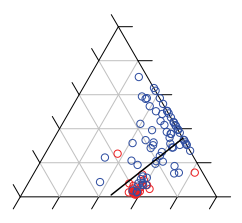

(e) 2005 Aug. 18

$674 \mathrm{~m}$
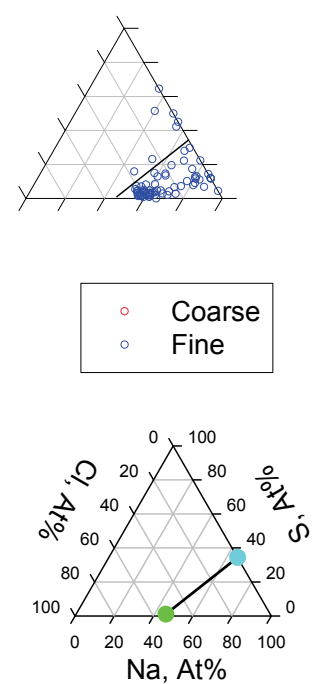

Fig. 7. Typical ternary plots of sea-salt constituents $(\mathrm{Na}, \mathrm{S}$ and $\mathrm{Cl})$ in coarse- and fine modes. Green and cyan circles show atomic ratios of bulk seawater and the wholly $\mathrm{Cl}$ depleted sea-salt particles with sulfates. The black line represents the stoichiometric line between bulk seawater and the wholly $\mathrm{Cl}$ depleted sea-salt particles. All plots are listed in the Supplement.

\subsubsection{Predominance of sulfate particles in the lower troposphere during winter through spring}

Although sea-salt particles were predominant near the surface during winter through spring, as described above, high relative abundance of sulfate particles was observed occasionally in the near surface to the lower boundary layer $(<500 \mathrm{~m}$ ), even during winter (e.g., 10 and 19 May, 16 and 28 June, 18 August), as depicted in Fig. 6. In contrast to the predominance of sea salt particles in high aerosol number density, high relative abundance of sulfate particles was coincident with the lower aerosol number density (Hara et al., $2011 \mathrm{~b}$ ). For instance, the relative abundance of sulfate particles was approximately $80 \%$ in fine mode below $500 \mathrm{~m}$ on 16 June 2005, whereas the relative abundance of seasalt and modified sea-salt particles increased by $60 \%$ above $700 \mathrm{~m}$ (Figs. 4 and 6). In addition, higher potential temperature and relative humidity were observed at altitudes greater than $700 \mathrm{~m}$ (Fig. 2). Backward trajectory from the sampling altitudes on 16 June revealed that air masses below $500 \mathrm{~m}$ were transported from the free troposphere over the Antarctic continent, whereas air masses above $700 \mathrm{~m}$ came from the boundary layer over the ocean $\left(55-60^{\circ} \mathrm{S}\right)$. Consequently, this profile and air mass history strongly suggest that warm and humid oceanic air masses mixed with a large amount of sea-salt particles flowed into the upper boundary layerlower free troposphere over Syowa Station. It is noteworthy that the tethered balloon operation was conducted only under conditions of calm winds and high pressure. A remarkably high abundance of sulfate particles during winter appeared over Syowa Station under high-pressure conditions.
This result was closely coincident with the high abundance of volatile particles near the surface in air parcels from the free troposphere over the continent during winter (Hara et al., 2011a). Consequently, sulfate particles were probably predominant in the free troposphere over the Antarctic continent and coasts during winter through spring. In the other cases with high abundance of sulfate particles in the lower troposphere during winter through spring, air masses had fallen from the free troposphere over the continent or coasts, which suggests that aerosol particles in the free troposphere had flowed to the boundary layer in the Antarctic coasts under high-pressure conditions during winter through spring.

\subsection{Seasonal and vertical variations of sea-salt modification}

As depicted in Fig. 6, modified sea-salt particles were identified in both the boundary layer and free troposphere, particularly during summer. Although seasonal features of seasalt modification near the surface at Antarctic coasts were shown by Mouri et al. (1999) and Hara et al. (2004), vertical gradients of sea-salt modification have not been reported for Antarctic regions. Seasonal and vertical features of sea-salt modification are examined in this section.

\subsubsection{Seasonal variations of sea-salt modification}

Figure 7 depicts examples of ternary plots of sea-salt constituents $(\mathrm{Na}, \mathrm{S}$ and $\mathrm{Cl}$ ) in coarse and fine modes. Sea-salt particles internally mixed with mineral particles were excluded from Fig. 7 to avoid misunderstanding of the sea-salt chemistry. In this study, internal mixtures of sea salts and 
minerals were few or none in each sample. Green and blue circles respectively denote atomic ratios of bulk seawater ratios and wholly $\mathrm{Cl}$ depleted sea-salt particles by sulfates. The black line represents the stoichiometric line from the seasalt particles with bulk seawater ratio to the Cl-depleted seasalt particles by sulfates. When $\mathrm{Cl}$ in a sea-salt particle is replaced stoichiometrically to $\mathrm{SO}_{4}^{2-}$ by heterogeneous reactions, each sea-salt particle is distributed along the stoichiometric line.

Sea-salt particles in coarse mode were distributed along the stoichiometric line in some samples taken in summer (e.g., 16 February as shown in Fig. 7a), so that the seasalt particles might be modified predominantly with sulfates. Most coarse sea-salt particles were distributed around the seawater ratio even in summer, although the $\mathrm{Cl}$ ratio was slightly lower than the seawater ratio. Compared to coarse sea-salt particles, sea-salt constituents were distributed widely in fine mode over Syowa Station. This suggests that sea-salt modification occurs preferentially in fine mode. A similar tendency was observed in previous investigations in Antarctic and Arctic regions (Mouri et al., 1999; Hara et al., 2002, 2005; Rankin and Wolff, 2003). Most of the modified sea-salt particles in fine mode were distributed in $\mathrm{Cl}$ ratio of ca. $0 \%$ and higher $\mathrm{S}$ atomic ratio relative to the modified sea-salt particles during summer (e.g., 16 February in Fig. 7a). Moreover, some sea-salt particles containing $\mathrm{Cl}$ in fine mode had a significantly larger $\mathrm{S}$ ratio relative to the stoichiometric line (e.g., 23 March, 23 April, and 11 December in Fig. 7b, c, and i), so that these sea-salt particles might be modified not only with $\mathrm{SO}_{4}^{2-}$ but also with $\mathrm{CH}_{3} \mathrm{SO}_{3}^{-}$, as suggested by Hara et al. (2005). The presence of the modified sea-salt particles containing excess sulfates implies that seasalt particles can act as important scavengers of condensable vapors and aerosol precursors such as $\mathrm{H}_{2} \mathrm{SO}_{4}$ gas.

As described above, relative abundance of sea-salt particles increased in mid-March through October. Coarse seasalt particles were distributed close to seawater ratio, especially on 23 March, 23 April, and 4 September, as shown in Fig. 7. In contrast to sea-salt particles in coarse mode, partly Cl-depleted sea-salt particles and the modified sea-salt particles were often identified in fine mode during winter through spring. Because of a higher $\mathrm{S}$ atomic ratio in partly $\mathrm{Cl}$ depleted sea-salt particles and the modified sea-salt particles, acidic sulfur species (predominantly $\mathrm{SO}_{4}^{2-}$ ) caused sea-salt modification in fine mode during winter through spring. Insignificant sea-salt modification corresponded to high abundance of sea-salt particles under aerosol-enhanced conditions (Antarctic haze, e.g., 28 May, 22 July, and 30 September). As described already, high abundance of sea-salt particles was the typical condition over Syowa Station, so that minor seasalt modification was typical during winter through spring, as suggested by Hara et al. $(2004,2005)$. With increased relative abundance of sulfate particles after October, more sea-salt particles in fine mode tended to be modified with sulfates, as shown in Fig. 7.
The atomic ratio of $\mathrm{Cl}$ in sea-salt particles, however, dropped to $40-45 \%$ in most cases in coarse and fine modes during winter through spring. We checked analytical conditions using artificial particles of pure $\mathrm{NaCl}$ and $\mathrm{Na}_{2} \mathrm{SO}_{4}$, but the analytical bias in EDX analysis cannot account for this difference. Because of a small change of the atomic ratio of $S$, the likelihood of sea-salt modification with acidic gases other than sulfates should be considered. Although previous investigations pointed out sea-salt modification by $\mathrm{NO}_{3}^{-}$(Mamane and Gottlieb, 1992; Hara et al., 1999) and organic acids (Laskin et al., 2012), the $\mathrm{NO}_{3}^{-}$concentration was higher than those of organic acids such as formate, acetate, and oxalate at Syowa Station during winter through spring (e.g., Hara et al., 2010a). Here, we attempt to estimate the $\mathrm{NO}_{3}^{-}$concentration to engender a decrease of several to $10 \%$ in $\mathrm{Cl}$ atomic ratio in coarse sea-salt particles, assuming that chemical constituents were homogeneous in sea-salt particles and that $\mathrm{NO}_{3}^{-}$causes sea-salt modification. Using the $\mathrm{Cl}$ atomic ratio and bulk $\mathrm{Na}^{+}$concentrations in the coarse mode obtained from bulk analysis (e.g., Hara et al., 2004, 2010a), the range of $\mathrm{NO}_{3}^{-}$concentration was estimated to be ca. $0.2 \mathrm{nmol} \mathrm{m}^{-3}$. The estimated $\mathrm{NO}_{3}^{-}$concentration was consistent with ambient $\mathrm{NO}_{3}^{-}$concentration in coarse mode, ranging below the detection limit (BDL) $0.4 \mathrm{nmol} \mathrm{m}^{-3}$ (annual mean, $0.04 \mathrm{nmol} \mathrm{m}^{-3}$ ) at Syowa Station (Hara et al., unpublished data). Therefore, slight sea-salt modification in coarse and fine modes might have occurred to a marked degree through heterogeneous $\mathrm{NO}_{3}^{-}$formation during winter through spring. The small contribution of $\mathrm{NO}_{3}^{-}$to sea-salt modification implies lower concentrations of $\mathrm{NO}_{3}^{-}$ precursors such as $\mathrm{HNO}_{3}, \mathrm{~N}_{2} \mathrm{O}_{5}$, and $\mathrm{NO}_{3}$ and high sea-salt concentration in the lower troposphere around the Antarctic coasts.

Significant $\mathrm{Cl}$ depletion from sea-salt particles, however, occurred on 18 August when sea-salt particles and the modified sea-salt particles were distributed in a lower $\mathrm{S}$ ratio relative to the stoichiometric line. As shown in Fig. 7e and in the Supplement, sea-salt particles on 18 August might have been modified considerably by heterogeneous $\mathrm{NO}_{3}^{-}$formation in the boundary layer and lower free troposphere in addition to sea-salt modification partly by sulfur species such as $\mathrm{SO}_{4}^{2-}$. Such a high contribution of $\mathrm{NO}_{3}^{-}$to sea-salt modification was observed only during August through September in this study. Previous investigations (Mouri et al., 1999: Hara et al., 2005) revealed the high contribution of $\mathrm{NO}_{3}^{-}$to sea-salt modification at Syowa Station in August. Backward trajectory on 18 August (see the Supplement) showed that air masses of each sampling altitude had traveled in the boundary layer and free troposphere over the Antarctic coast along the coastline without marked vertical mixing during the prior 5 days. In particular, the air parcel at $1430 \mathrm{~m}$ might have traveled for at least 5 days in the free troposphere. Consequently, the marked sea-salt modification by $\mathrm{NO}_{3}^{-}$implies that the concentrations of $\mathrm{NO}_{3}^{-}$precursors such as $\mathrm{HNO}_{3}, \mathrm{~N}_{2} \mathrm{O}_{5}$, 
and $\mathrm{NO}_{3}$ are enhanced in the boundary layer and lower free troposphere over the Antarctic coast from August through September.

\subsubsection{Vertical features of sea-salt modification in coarse mode}

Figure 8 portrays examples of vertical features of atomic ratios of $\mathrm{Cl} / \mathrm{Na}$ and $\mathrm{S} / \mathrm{Na}$ in coarse sea-salt particles over Syowa Station. All plots are listed in the Supplement information. Because of the diminished concentrations in coarse mode January-February and mid-NovemberDecember (Hara et al., 2011b), the vertical features of seasalt modification in coarse mode were uncertain in most cases. On 16 February, 21 November and 28 November, $\mathrm{Cl} / \mathrm{Na}$ ratios of sea-salt particles in coarse mode varied greatly and lower $\mathrm{Cl} / \mathrm{Na}$ ratios were observed in the boundary layer and lower free troposphere. Furthermore, high $\mathrm{S} / \mathrm{Na}$ ratios corresponded to low $\mathrm{Cl} / \mathrm{Na}$ ratios, which might have resulted from sea-salt modification with sulfate and methanesulfonate, as discussed above.

Median $\mathrm{Cl} / \mathrm{Na}$ ratios in coarse mode were $0.75-1.3$ in the boundary layer and the free troposphere from winter through spring (April-October), except in the sample collected near or in a cloud layer $(934 \mathrm{~m})$ on 23 April. Median S / Na ratios in coarse mode ranged mostly ca. 0.05 during winter through spring. Furthermore, variation of $\mathrm{Cl} / \mathrm{Na}$ and $\mathrm{S} / \mathrm{Na}$ ratios became smaller in the boundary layer and lower free troposphere. Significant vertical features of $\mathrm{Cl} / \mathrm{Na}$ and $\mathrm{S} / \mathrm{Na}$ ratios of sea-salt particles in coarse mode were not identified winter through spring. Higher $\mathrm{Cl} / \mathrm{Na}$ ratios than 1 , however, were observed occasionally in the boundary layer (e.g., 23 April, 19 May, 22 July and 4 September). Particularly, median $\mathrm{Cl} / \mathrm{Na}$ ratios at $47 \mathrm{~m}$ on 23 April reached ca. 1.35 (mean ratio, ca. 1.30). Because $\mathrm{Cl} / \mathrm{Na}$ ratios in seawater (e.g., Wilson, 1975) are ca. 1.18, the higher $\mathrm{Cl} / \mathrm{Na}$ ratio suggests strongly that $\mathrm{Cl}$ was enriched in sea-salt particles by sea-salt fractionation winter through spring, as reported by Hara et al. (2012). In contrast, the $\mathrm{Cl} / \mathrm{Na}$ ratio (ca. 0.75) in most cases was slightly lower than the seawater ratio. As discussed in Sect. 3.6.1, this might have resulted from slight sea-salt modification with $\mathrm{NO}_{3}^{-}$.

\subsubsection{Vertical features of sea-salt modification in fine mode}

Figure 9 portrays examples of vertical features of atomic ratios of $\mathrm{Cl} / \mathrm{Na}$ and $\mathrm{S} / \mathrm{Na}$ in fine sea-salt particles over Syowa Station. All plots are listed in the Supplement. Median $\mathrm{Cl} / \mathrm{Na}$ and $\mathrm{S} / \mathrm{Na}$ ratios in sea-salt particles and the modified sea-salt particles ranged mostly in $<0.2$ and $>0.5$, respectively, in the boundary layer and lower free troposphere during summer. This range implies that fine sea-salt particles preferred to be modified relative to coarse sea-salt particles in both the boundary layer and lower free tropo- sphere, especially during summer (January-mid-March and mid-November-December). For example, modified sea-salt particles were distributed in the boundary layer and lower free troposphere on 14 March (Fig. 9). Because lower $\mathrm{Cl} / \mathrm{Na}$ ratios were found in higher $\mathrm{S} / \mathrm{Na}$ ratios in the boundary layer and the free troposphere, acidic sulfur species such as $\mathrm{SO}_{4}^{2-}$ and $\mathrm{CH}_{3} \mathrm{SO}_{3}^{-}$might contribute to sea-salt modification in fine modes, as discussed in Sect. 3.6.2. Although higher $\mathrm{Cl} / \mathrm{Na}$ ratios were obtained at altitudes greater than $500 \mathrm{~m}$ on 5 December 2005, air masses with higher $\mathrm{Cl} / \mathrm{Na}$ ratios were transported from the boundary layer over the ocean during the prior 5 days. Conversely, lower $\mathrm{Cl} / \mathrm{Na}$ ratios in most cases during summer corresponded to transport from the Antarctic coast and continent during the prior 5 days. Consequently, the vertical features might be attributed to the air mass history and aging time of sea-salt modification. According to the comparison between $\mathrm{Cl} / \mathrm{Na}$ ratios and air mass history, it appears to take longer than 5 days for complete $\mathrm{Cl}$ depletion in fine sea-salt particles around the Antarctic coasts during summer.

Although the median $\mathrm{Cl} / \mathrm{Na}$ ratio in coarse mode was greater than 0.75 during April through November, a lower median $\mathrm{Cl} / \mathrm{Na}$ ratio and large variance of $\mathrm{Cl} / \mathrm{Na}$ ratio were identified in the boundary layer and lower free troposphere even in winter. This suggests strongly that sea-salt modification proceeded with preference in fine mode in the boundary layer and lower free troposphere even during winter through spring over Syowa Station. As shown in Fig. 9 and in the Supplement, vertical features of median $\mathrm{Cl} / \mathrm{Na}$ ratios in fine sea-salt particles during winter through spring are classifiable as (1) almost constant $\mathrm{Cl} / \mathrm{Na}$ ratios (e.g., 28 May, 22 July, 30 September), (2) lower $\mathrm{Cl} / \mathrm{Na}$ ratios in the lower boundary layer (e.g., 19 May, 16 June, 28 June, and 17 September), or (3) lower $\mathrm{Cl} / \mathrm{Na}$ ratios in the upper boundary layer and lower free troposphere (e.g., 10 May, 18 August, and 4 September).

In the first type, vertical features of variation of $\mathrm{Cl} / \mathrm{Na}$ ratios in fine mode tended to be smaller. The median $\mathrm{Cl} / \mathrm{Na}$ and $\mathrm{S} / \mathrm{Na}$ ratios were approximately $0.75-0.80$ and $<0.2$, respectively, in the boundary layer and lower free troposphere. This type was observed in the cases of higher relative abundance of sea-salt particles in the boundary layer under aerosol-enhanced conditions (Antarctic haze), as depicted in Fig. 6. The backward trajectory shows that air masses came from ocean and sea ice regions to the observed area over Syowa Station during the prior 5 days. Therefore, sea-salt emissions from the ocean surface and sea ice and rapid transport to Syowa Station might cause some slight sea-salt modification in the boundary layer and lower free troposphere. With the suggestion of predominance of sea-salt particles (Hara et al., 2004) and slight sea-salt modification during winter (Hara et al., 2005, 2010a), the first type might be predominant in Antarctic coasts under usual winter conditions with stronger winds. 


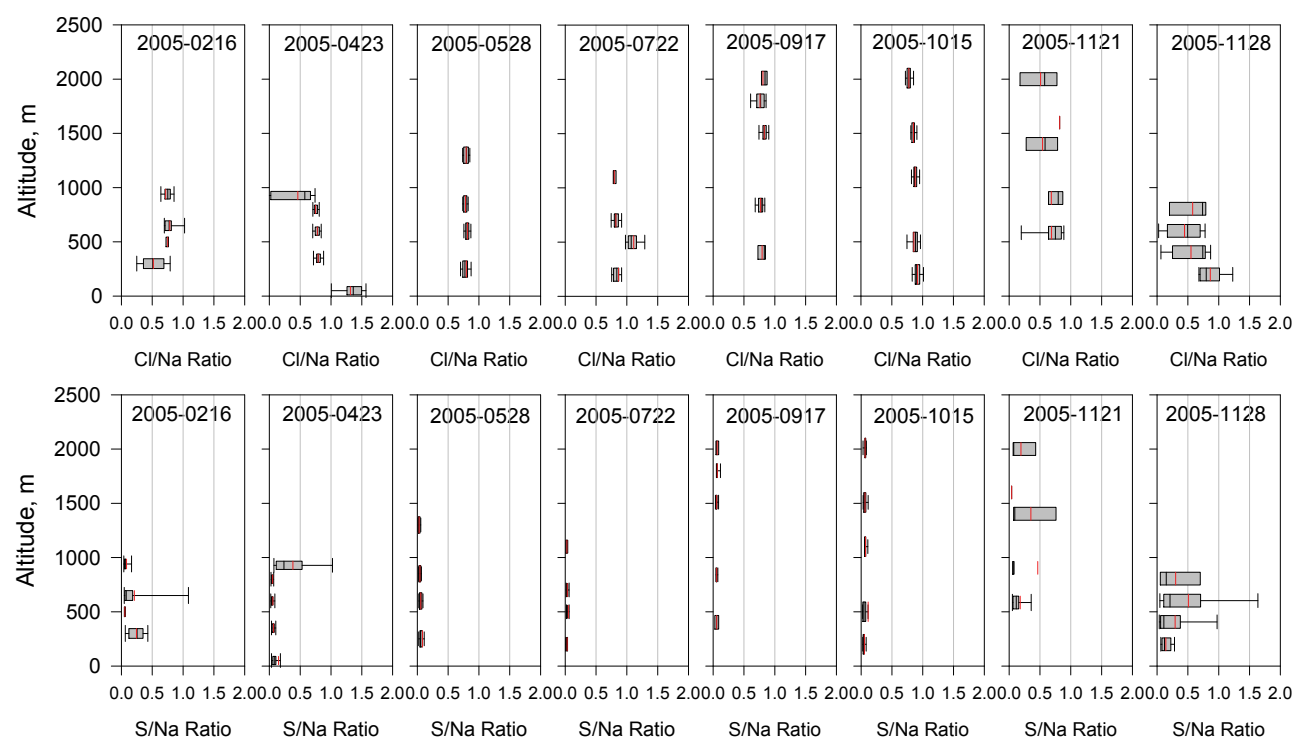

Fig. 8. Typical vertical features of atomic ratios of $\mathrm{Cl} / \mathrm{Na}$ and $\mathrm{S} / \mathrm{Na}$ in coarse mode. In box plots, the right bar, right box line, black middle box line, left box line, and left bar respectively denote values of $90 \%, 75 \%, 50 \%$ (median), $25 \%$, and $10 \%$. The red line shows mean values. All plots are listed in the Supplement.

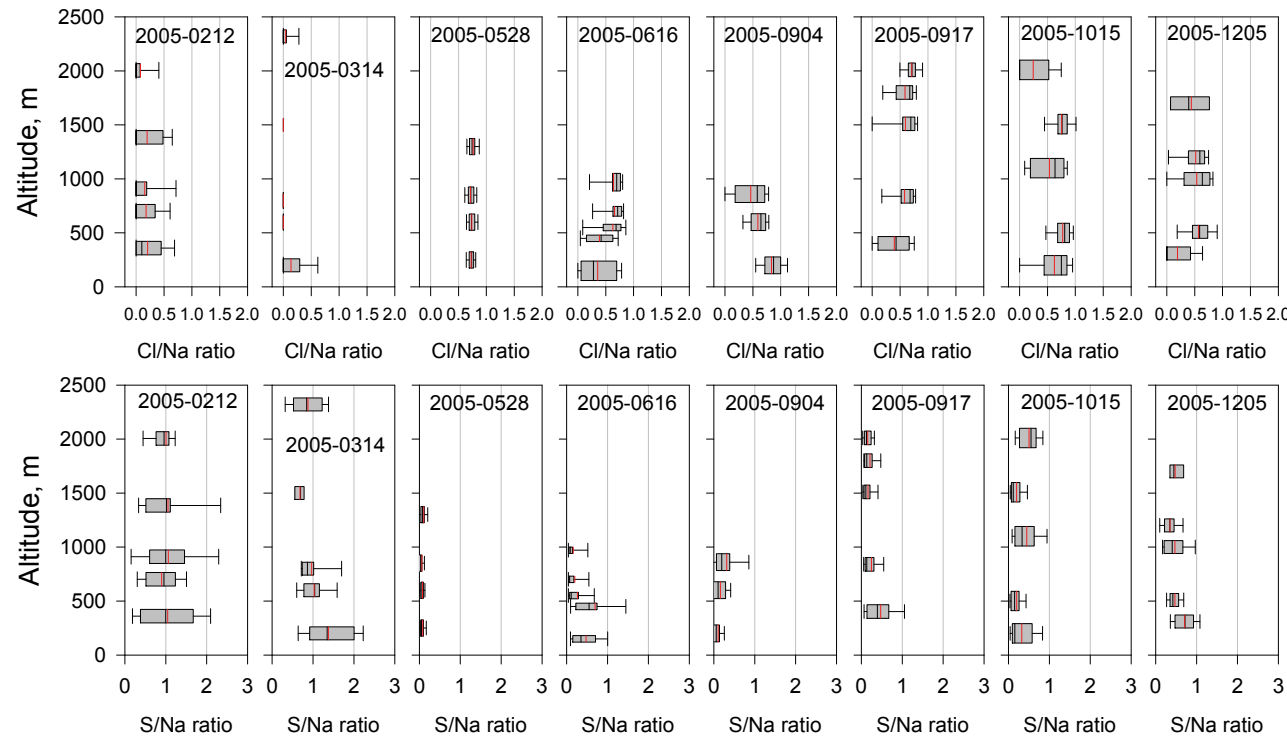

Fig. 9. Typical vertical features of atomic ratios of $\mathrm{Cl} / \mathrm{Na}$ and $\mathrm{S} / \mathrm{Na}$ in fine mode. In box plots, the right bar, right box line, black middle box line, left box line, and left bar respectively denote values of $90 \%, 75 \%, 50 \%$ (median), 25\%, and $10 \%$. The red line shows mean values. All plots are listed in the Supplement.

In the second type, lower $\mathrm{Cl} / \mathrm{Na}$ ratios were observed remarkably in the lower boundary layer, when higher abundance of sulfate particles was obtained in the boundary layer. In spite of the appearance of sea-salt particles with lower $\mathrm{Cl} / \mathrm{Na}$ ratios in the lower boundary layer, the median $\mathrm{Cl} / \mathrm{Na}$ ratios reached $0.7-0.9$ in the upper boundary layer and lower free troposphere. On 16 June (Fig. 3), sea-salt particles with lower $\mathrm{Cl} / \mathrm{Na}$ and high $\mathrm{S} / \mathrm{Na}$ ratios below $500 \mathrm{~m}$ were present in air masses from the free troposphere over the Antarctic continent, whereas air masses with higher $\mathrm{Cl} / \mathrm{Na}$ ratio came from sea ice and ocean areas. A similar air mass history was obtained in the other cases of the second type. Moreover, ternary plots of sea salts $(\mathrm{Na}, \mathrm{S}$ and $\mathrm{Cl})$ in the second type imply that $\mathrm{SO}_{4}^{2-}$ makes a substantial contribution to sea-salt modification in fine mode (Fig. 7 and in the Supplement). According to Minikin et al. (1998) and Moore and Abbott (2002), acidic sulfur species such as $\mathrm{SO}_{4}^{2-}$ and $\mathrm{CH}_{3} \mathrm{SO}_{3}^{-}$ in aerosol particles are linked to oceanic biogenic activity in 
the coastal Antarctic regions during summer, but less so during winter. Indeed, the high $\mathrm{Cl} / \mathrm{Na}$ and lower $\mathrm{S} / \mathrm{Na}$ ratios in the sea-salt particles in lower free troposphere and upper boundary layer were obtained in air masses transported from ocean and sea ice regions, as shown in Figs. 8 and 9. Consequently, the concentrations of gaseous acidic sulfur species might be insufficiently high to engender rapid sea-salt modification within several days. Nevertheless, significant sea-salt modification with acidic sulfur species (e.g. $\mathrm{SO}_{4}^{2-}$ ) was obtained for air masses transported from the free troposphere over the continent in these cases. Because of the longer lifetime resulting from lower solar radiation, large amounts of sulfur aerosol precursors such as DMS and DMSO were observed during winter at Dumont d'Urville Station, Antarctica (Jourdain and Legrand, 2001) and at Concordia Station on the high Antarctic plateau (Preunkert et al., 2008). Therefore, sea-salt particles might be modified by heterogeneous reactions and coagulation for longer suspension periods in the free troposphere over Antarctica, even during winter through spring. Then, outflow of air masses in the free troposphere over the Antarctic continent to the boundary layer in the Antarctic coast might create vertical features of sea-salt modification in the second type.

In the third type, the vertical gradients of $\mathrm{Cl} / \mathrm{Na}$ ratios were observed in the boundary layer-lower free troposphere (e.g., 10 May, 18 August, and 4 September), as shown in Fig. 9 and in the Supplement. For instance, median $\mathrm{Cl} / \mathrm{Na}$ ratios changed gradually from 0.88 at $230 \mathrm{~m}$ to 0.57 at $850 \mathrm{~m}$ on 4 September. With the vertical gradient of $\mathrm{Cl} / \mathrm{Na}$ ratios, $\mathrm{S} / \mathrm{Na}$ ratios increased gradually in the upper boundary layer on both days. Ternary plots (Na-S-Cl) on 4 September revealed a substantial contribution of $\mathrm{SO}_{4}^{2-}$ to sea-salt modification in fine mode, as shown in the Supplement. Moreover, higher relative humidity was identified at altitudes with lower $\mathrm{Cl} / \mathrm{Na}$ ratios. The relative humidity changed from ca. $45 \%$ near the surface to ca. $94 \%$ at $850 \mathrm{~m}$ on 4 September. High relative humidity was obtained at altitudes with lower $\mathrm{Cl} / \mathrm{Na}$ ratio on other days. As inferred from previous investigations conducted by von Glasow and Sander (2001) and by Hara et al. (2002), sea-salt modification occurs to a considerable degree under conditions with higher relative humidity. Therefore, the vertical gradients of $\mathrm{Cl} / \mathrm{Na}$ and $\mathrm{S} / \mathrm{Na}$ on 10 May and 4 September might result from enhancement of sea-salt modification under conditions with vertical gradients of relative humidity.

\subsection{Sea-salt fractionation over Syowa Station}

As shown in Fig. 5b, Mg-enriched sea-salt particles were occasionally identified in this study. As suggested by our previous studies (Hara et al., 2005, 2010a, 2012), Mg-enriched sea-salt particles might be associated with sea-salt fractionation on sea ice. Seasonal variations of the fractionated seasalt particles are discussed in this section.

\subsubsection{Seasonal variations of sea-salt fractionation}

Figure 10 depicts examples of ternary plots of sea-salts (Na, $\mathrm{Mg}$, and S) and Mg-rich sulfates in coarse and fine modes. Internal mixtures of sea salts and minerals were removed from the ternary plots to avoid misunderstanding. In the ternary plots, sea-salt particles with bulk seawater ratio are distributed around the blue circle (bulk seawater ratio). When the sea-salt particles are modified by sulfate and not fractionated, they are distributed around the stoichiometric line between the blue circle (seawater ratio) and red circle (modified sea-salt ratio with sulfate). With sea-salt fractionation by precipitation of Na-salts such as mirabilite $\left(\mathrm{Na}_{2} \mathrm{SO}_{4} 10 \mathrm{H}_{2} \mathrm{O}\right)$ and hydrohalite $\left(\mathrm{NaCl} 2 \mathrm{H}_{2} \mathrm{O}\right.$ ) (Hara et al., 2012), $\mathrm{Mg}$ in seasalt particles can be enriched gradually during winter through spring. For cases in which sea-salt fractionation (replacement between $\mathrm{Na}$ and $\mathrm{Mg}$ ) occurs without sea-salt modification by sulfate, sea-salt particles are distributed around the stoichiometric line between the blue circle (bulk seawater ratio) and cyan circle $\left(\mathrm{MgCl}_{2}\right)$. When sea-salt fractionation and sea-salt modification by sulfate occur stoichiometrically and simultaneously, sea-salt particles are distributed around the stoichiometric line between the blue circle (seawater ratio) and green circle $\left(\mathrm{MgSO}_{4}\right)$.

Because sea-salt modification occurred during summer, sea-salt particles in coarse and fine modes were distributed around the stoichiometric lines of sea-salt modification with sea-salt fractionation or sea-salt modification without seasalt fractionation. $\mathrm{Mg}$ ratios in fine sea-salt particles differed greatly from those in coarse mode. The $\mathrm{Mg}$ ratios in coarse sea-salt particles ranged mostly from several percent to $20 \%$ in summer, whereas many sea-salt particles in fine mode were distributed at $\mathrm{Mg}$ ratio $\approx 0$ and the higher $\mathrm{S}$ ratios relative to the stoichiometric line between the blue circle and green circle. Hereinafter, we designate sea-salt particles with $\mathrm{Mg}$ ratio $\approx 0$ as "Mg-free sea-salt particles".

After end of March, most sea-salt particles in coarse mode were distributed around the seawater ratio, although a slightly higher $\mathrm{Mg}$ ratio (ca. 20\%) was obtained in some sea-salt particles (Fig. 10b and c). According to the comparison with $\mathrm{Mg}$ ratio during summer, $\mathrm{Mg}$ ratio in fine mode increased gradually after the end of March. For example, the highest $\mathrm{Mg}$ ratio in fine mode was ca. $40 \%$ on 23 March and $78 \%$ on 23 April in the ternary plots (Fig. 10b and c). The presence of sea-salt particles with slightly high Mg enrichment suggests that sea-salt fractionation started to occur around Syowa Station at the end of March and April, when air temperatures near the surface dropped occasionally to lower than $-9^{\circ} \mathrm{C}$ (Hara et al., 2012). In contrast, the number of $\mathrm{Mg}$-free sea-salt particles tended to decrease.

During winter, sea-salt particles in coarse and fine modes were distributed markedly around the stoichiometric line of sea-salt fractionation without sea-salt modification. For instance, the $\mathrm{Mg}$ ratios exceeded $60 \%$ in coarse mode on 22 July (see Fig. 10 and the Supplement). This strongly suggests 


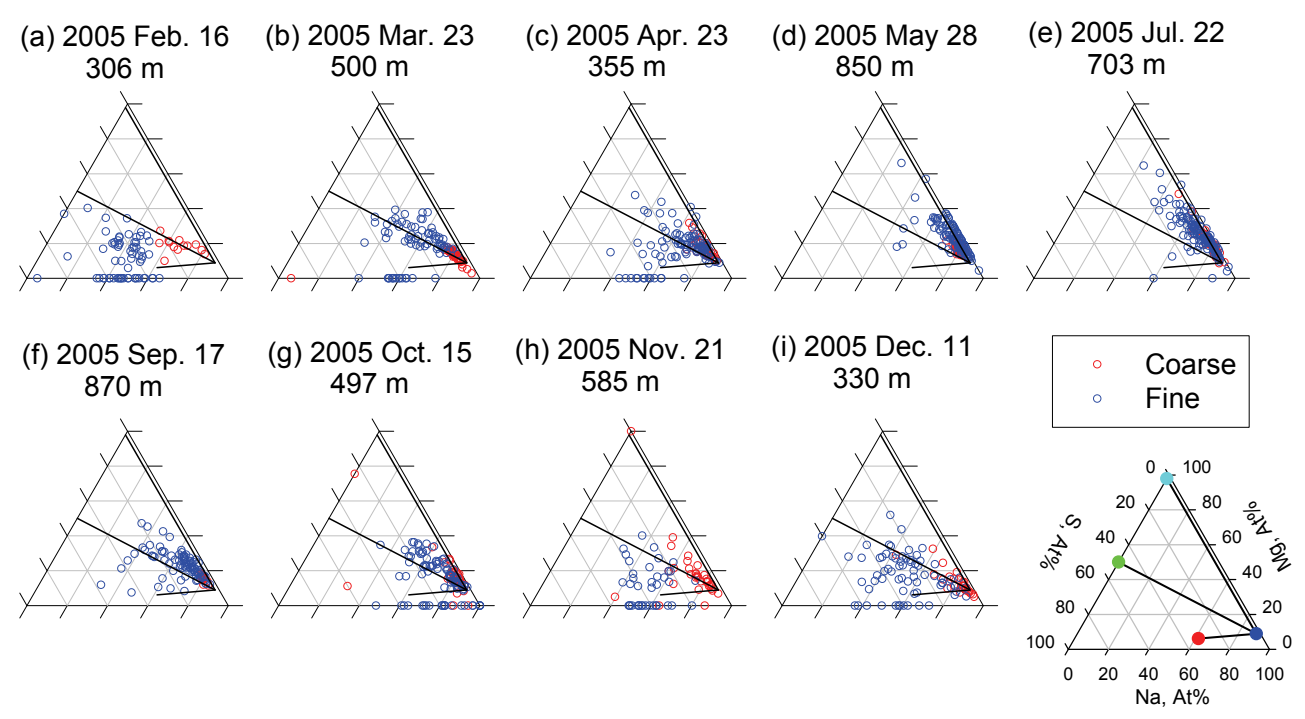

Fig. 10. Typical ternary plots of sea salts $(\mathrm{Na}, \mathrm{Mg}$, and $\mathrm{S})$ in coarse and fine modes. Blue, red, cyan, and green circles respectively denote atomic ratios of (1) bulk seawater, (2) wholly $\mathrm{Cl}$ depleted sea-salt particles with sulfates, (3) $\mathrm{MgCl}_{2}$, and (4) $\mathrm{MgSO}_{4}$. $\mathrm{Black}$ lines represent stoichiometric lines among constituents. All plots are listed in the Supplement.

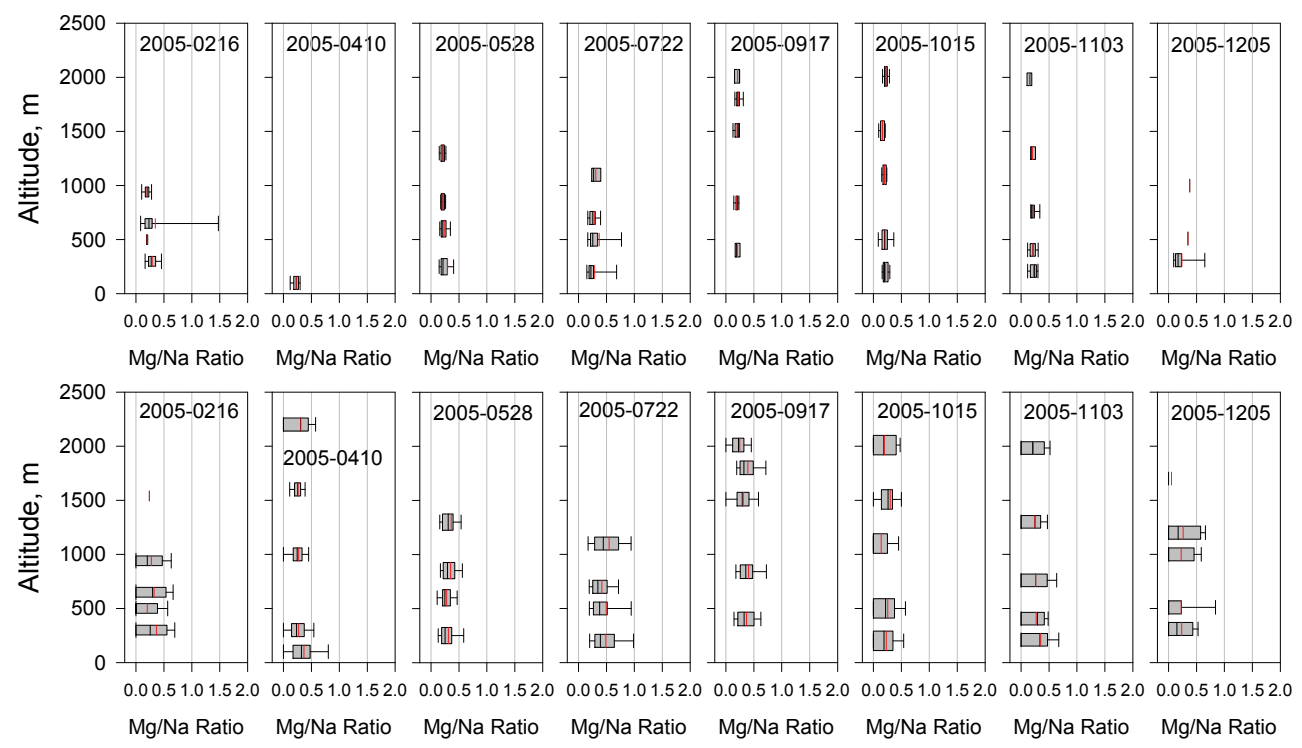

Fig. 11. Typical vertical features of atomic ratios of $\mathrm{Mg} / \mathrm{Na}$ in coarse and fine modes over Syowa Station. In box plots, the right bar, right box line, black middle box line, left box line, and left bar respectively denote values of $90 \%, 75 \%, 50 \%$ (median), $25 \%$, and $10 \%$. The red line shows mean values. All plots are listed in the Supplement.

that $\mathrm{Mg}$ was enriched in sea-salt particles by sea-salt fractionation during winter. In addition, large variation of $\mathrm{Mg}$ ratios suggests that sea-salt constituents were heterogeneous along the Antarctic coast. High Mg enrichment in winter through spring was identified also in bulk aerosol data at Syowa Station (Hara et al., 2012). Ternary plots of Na-Mg-S (Fig. 10) and $\mathrm{Na}-\mathrm{Mg}-\mathrm{Cl}$ (not shown) imply that $\mathrm{Mg}$ is present in coarse sea-salt particles as $\mathrm{MgCl}_{2}$. Therefore, aerosol particles containing mostly $\mathrm{MgCl}_{2}$ (Fig. $5 \mathrm{~h}$ ) might be associated with sea-salt fractionation on sea ice. Although Mg-free sea- salt particles were identified rarely in fine mode during May through August, the number of Mg-free sea-salt particles increased again in September (Fig. 10 and the Supplement). Furthermore, some particles were distributed around the ratio of $\mathrm{MgSO}_{4}$ (green circle). The distribution around the stoichiometric line of sea-salt fractionation with sea-salt modification strongly implies that $\mathrm{MgSO}_{4}$ particles were derived from sea-salt fractionation and sea-salt modification.

Mg-enriched sea-salt particles can be formed through sea-salt fractionation by precipitation of mirabilite and 
hydrohalite on sea ice under cold conditions (Hara et al., 2012 and references therein), but Mg-free sea-salt particles cannot be formed. Indeed, Mg-free sea-salt particles were identified only rarely during winter in this study. To explain the presence of external mixtures of $\mathrm{MgSO}_{4}$ particles, $\mathrm{Mg}$ rich sea-salt particles and $\mathrm{Mg}$-free sea-salt particles in summer, it is necessary to discuss $\mathrm{Mg}$ separation processes in the Antarctic regions that occur during summer. Although sea-salt fractionation by $\mathrm{Mg}$ separation processes has not been identified, the likelihood of $\mathrm{Mg}$ separation in sea-salt particles was pointed out from continuous aerosol measurements near the surface at Syowa Station (Hara et al., 2012). $\mathrm{Mg}$-enrichment and $\mathrm{Mg}$-depletion have not been identified in sea-salt particles produced by bubble bursting (Keene et al., 2007). Considering the seasonality of the presence of $\mathrm{Mg}$-free sea-salt particles, $\mathrm{Mg}$ separation in sea-salt particles might occur preferentially during summer in Antarctic regions. As described in Sect. 3.4.2, $\mathrm{MgSO}_{4}$ particles were observed in air masses from the Antarctic continent and coasts. Therefore, we propose that $\mathrm{Mg}$-separation proceeds in Antarctic regions during summer.

\subsubsection{Vertical features of fractionated sea-salt particles}

Figure 11 depicts examples of vertical features of $\mathrm{Mg} / \mathrm{Na}$ ratios in coarse and fine modes over Syowa Station. Although median $\mathrm{Mg} / \mathrm{Na}$ ratios in coarse mode were mostly lower than 0.2 in the boundary layer and free troposphere during summer (January-March and November-December), the median ratios in coarse mode were larger than 0.2 in the boundary layer-lower free troposphere during winter through spring (April-October). During winter, highly $\mathrm{Mg}$ enriched sea-salt particles in coarse mode $(\mathrm{Mg} / \mathrm{Na}>0.3)$ were occasionally identified in the boundary layer (e.g., 28 May and 22 July). In addition, $\mathrm{Mg} / \mathrm{Na}$ ratios on 28 May were smaller in the air masses of lower free troposphere, which were transported from the boundary layer above open sea areas. In contrast to $\mathrm{Mg} / \mathrm{Na}$ ratio in coarse mode, median $\mathrm{Mg} / \mathrm{Na}$ ratios in fine mode decreased occasionally to 0 during summer because of the presence of $\mathrm{Mg}$-free seasalt particles. Sea-salt fractionation by $\mathrm{Mg}$ separation might engender greater variation of $\mathrm{Mg} / \mathrm{Na}$ ratios in fine sea-salt particles during summer. Median $\mathrm{Mg} / \mathrm{Na}$ ratios in fine mode were greater than 0.2 in the boundary layer-lower free troposphere during winter through spring. Compared to the vertical features of $\mathrm{S} / \mathrm{Na}$ and $\mathrm{Cl} / \mathrm{Na}$ ratios, however, vertical gradients of $\mathrm{Mg} / \mathrm{Na}$ ratios were not statistically significant in coarse or fine modes in the lower troposphere, perhaps because of (1) the slight change of $\mathrm{Mg} / \mathrm{Na}$ ratios by sea-salt fractionation during winter relative to Cl-loss, and (2) well dispersion and mixing of the fractionated sea-salt particles in the lower troposphere $(<2500 \mathrm{~m})$ under observable conditions using the tethered balloon.

\section{Summary and conclusions}

Tethered balloon-borne aerosol measurements were conducted at Syowa Station, Antarctica, during January through December 2005. From single particle analysis using SEMEDX, sulfate particles, sulfate particles containing $\mathrm{K}$, $\mathrm{MgSO}_{4}$ particles, $\mathrm{MgCl}_{2}$ particles, sea-salt particles, $\mathrm{Mg}$ enriched sea-salt particles, wholly $\mathrm{Cl}$-depleted sea-salt particles, $\mathrm{Mg}$-free sea-salt particles, and mineral particles were identified in this study. Major aerosol constituents were sulfates during summer and sea-salt particles during winter through spring in the boundary layer and free troposphere over Syowa Station. Sulfate particles containing K were identified mostly in fine mode in the boundary layer and free troposphere. Sulfate particles containing K might have resulted from long-range transport after origination during combustion processes in South America and southern Africa. $\mathrm{MgSO}_{4}$ particles were also mainly distributed in fine mode.

Sulfate particles were major aerosol constituents in fine mode in both the boundary layer and free troposphere during summer. In contrast to fine mode, sea-salt particles and the modified sea-salt particles were predominant in coarse mode in the boundary layer. High relative abundance of sulfate particles was obtained even in coarse mode in the lower free troposphere. Relative abundance of sea-salt particles increased in coarse and fine modes during winter through spring in the boundary layer and lower free troposphere. Under conditions with higher aerosol number density and air mass transport from the boundary layer over sea ice and Southern Ocean, the relative abundance of sea-salt particles reached $<90 \%$ in coarse and fine modes. Because strong winds were typical conditions at Syowa Station during winter through spring, high relative abundance of sea-salt particles could have been the usual condition. When air mass in the free troposphere had descended into the boundary layer over Syowa Station, higher relative abundance of sulfate particles was identified occasionally in the boundary layer even in winter. This higher relative abundance implies that the relative abundance of sulfate particles might be high in free troposphere over Antarctic continent and coasts, although aerosol number concentrations were lower, as shown in Hara et al. (2011b). When air mass in the free troposphere had descended into the boundary layer over Syowa Station, air masses with higher relative abundance of sea-salt particles were lifted from the boundary layer over sea ice and the Southern Ocean to the upper boundary layer and lower free troposphere over Syowa Station.

Sea-salt particles in coarse and fine modes were modified mostly with $\mathrm{SO}_{4}^{2-}$ and $\mathrm{CH}_{3} \mathrm{SO}_{3}^{-}$through heterogeneous reactions during summer. Sulfates (and methanesulfonates) were enriched remarkably in the wholly $\mathrm{Cl}$-depleted seasalt particles. Furthermore, comparison with aerosol chemical data from bulk analysis implies that sea-salt particles were modified slightly with $\mathrm{NO}_{3}^{-}$throughout the year. It is noteworthy that $\mathrm{NO}_{3}^{-}$made a significant contribution to 
sea-salt modification in the boundary layer and lower free troposphere in August. Vertical features of sea-salt modification during winter through spring were classified into three types: (1) non-significant vertical features (less modification), (2) high modification in the lower boundary layer, and (3) high modification in the upper boundary layer and lower free troposphere. Insignificant vertical features of seasalt modification were identified in cases of the high aerosol number density, high relative abundance of sea-salt particles, and transport from sea ice and the Southern Ocean. For the first type these might be typical conditions of vertical features of sea-salt modification during winter through spring. The second type was observed in cases of high relative abundance of sulfate particles in the lower boundary layer. Considering the air mass history in high relative abundance of sulfate particles during winter, sea-salt particles might be modified gradually for longer than 5 days during their transport in the free troposphere even during winter through spring. The third type was often obtained under conditions with strong vertical gradient of relative humidity in the well-mixed boundary layer. As suggested in earlier reports (von Glasow and Sander, 2001; Hara et al., 2003), seasalt modification might be enhanced under conditions with higher relative humidity.

Mg-rich sea-salt particles were identified noticeably in coarse and fine modes during April through November through sea-salt fractionation on sea ice. During winter, $\mathrm{Mg}$ in sea-salt particles might occur in the form of $\mathrm{MgCl}_{2}$. During late spring through summer, $\mathrm{Mg}$-enriched sea-salt particles and Mg-free sea-salt particles were observed in this study. The Mg separation processes might occur in Antarctic regions during late spring through summer, although specific processes remain unknown.

\section{Supplementary material related to this article is available online at: http://www.atmos-chem-phys.net/13/ 9119/2013/acp-13-9119-2013-supplement.pdf.}

Acknowledgements. We would like to thank K. Matsubara (JARE46 leader, JMA), and K. Watanabe (JARE46 wintering leader; NIPR) for useful comments related to field operations around Syowa Station. Furthermore, we are grateful to T. Sato, H. Nishimaki, H. Yamamoto, T. Iwaki, D. Ito, S. Tasaka, A. Furusaki, M. Igarashi, T. Uemura, T. Okudaira, Y. Hasegawa, T. Yamazaki, H. Mizobuchi, M. Ikeda, K. Egawa, H. Takahashi, I. Okabayashi, and E. Kishimoto for help with tethered balloon operations under severe conditions, and to A. Yukimatsu, T. Matsumoto, M. Shuto, Y. Takagi, M. Kobayashi, H. Hamamoto, K. Harada, J. Fujii, K. Harigae, and Y. Ohmi for help with logistic work. Training of tethered balloon operations was conducted at the aerological observatory at Tsukuba, Japan, through cooperation with Y. Shuto (JMA), and T. Kimura (aerological observatory), who also provided useful and helpful comments related to tethered balloon operation. Useful comments for balloon operations in Antarctic regions were also offered by N. Hirasawa (NIPR) and K. Sato (The Univ. of Tokyo). This study was supported by "Observation project of global atmospheric change in the Antarctic" for JARE 43-47. This work was also supported by a Grant-in Aid (No. 16253001, PI: T. Yamanouchi) from the Ministry of Education, Culture, Sports, Science and Technology of Japan. The authors gratefully acknowledge the NOAA Air Resources Laboratory (ARL) for provision of the HYSPLIT transport and dispersion model and the READY website (http://www.arl.noaa.gov/ready.html) used in this publication.

Edited by: T. Kirchstetter

\section{References}

Bodhaine, B. A.: Aerosol absorption measurements at Barrow, Mauna Loa and the South Pole, J. Geophys. Res., 100, 89678975, 1995.

Bromwich, D. H., Nicolas, J. P., Hines, K., M., Kay, J. E., Key, E. L., Lazzara, M. A., Lubin, D., McFarquhar, G. M., Gorodetskaya, I. V., Grosvenor, D. P., Cope, T. L., and van Lipzig, N. P. M.: Tropospheric clouds in Antarctica, Rev. Geophys., 50, RG1004, doi:10.1029/2011RG000363, 2012.

Draxler, R. R. and Rolph, G. D.: HYSPLIT (HYbrid Single-Particle Lagrangian Integrated Trajectory) Model access via NOAA ARL READY Website (http://ready.arl.noaa.gov/HYSPLIT. php), NOAA Air Resources Laboratory, Silver Spring, MD, USA, 2013.

Elsässer, C., Wagenbach, D., Weller, R., Aueri, M., Wallner, A., and Christl, M.: Continuous 25-yr aerosol records at coastal Antarctica Part 2: Variability of the radionuclides ${ }^{7} \mathrm{Be},{ }^{10} \mathrm{Be}$ and ${ }^{210} \mathrm{~Pb}$, Tellus, 63B, 920-934, 2011.

Fiebig, M., Lunder, C. R., and Stohl, A.: Tracing biomass burning aerosol from South America to Troll Research Station, Antarctica, Geophys. Res. Lett., 36, L14815, doi:10.1029/2009GL038531, 2009.

Hara, K., Kikuchi, T., Furuya, K., Hayashi, M., and Fujii, Y.: Characterization of Antarctic aerosol particles using laser microprobe mass spectrometry, Environ. Sci. Technol., 30, 385-391, 1995.

Hara, K., Osada, K., Hayashi, M., Matsunaga, K., Shibata, T., Iwasaka, Y., and Furuya, K.: Fractionation of Inorganic Nitrates in Winter Arctic Troposphere - Coarse Aerosol Particles Containing Inorganic Nitrates, J. Geophys. Res., 104, 23671-23679, 1999.

Hara, K., Osada, K., Nishita, C., Yamagata, S., Yamanocuhi, T., Herber, A., Matsunaga, K., Iwasaka, Y., Nagatani, M., and Nakada, H.: Vertical variations of sea-salt modification in the boundary layer of spring Arctic during the ASTAR 2000 campaign, Tellus, 54, 361-376, 2002.

Hara, K., Yamagata, S., Yamanocuhi, T., Sato, K., Herber, A., Iwasaka, Y., Nagatani, M., and Nakada, H.: Mixing states of individual aerosol particles in spring Arctic troposphere during ASTAR 2000 campaign, J. Geophys. Res., 108, 4209, doi:10.1029/2002JD002513, 2003.

Hara, K., Osada, K., Kido, M., Hayashi, M., Matsunaga, K., Iwasaka, Y., Yamanouchi, T., Hashida, G., and Fukatsu, T.: Chemistry of sea-salt particles and inorganic halogen species in Antarctic regions: Compositional differences between 
coastal and inland stations, J. Geophys. Res., 109, D20208, doi:10.1029/2004JD004713, 2004.

Hara, K., Osada, K., Kido, M., Matsunaga, K., Iwasaka, Y., and Hashida, G.: Seasonal variations of sea-salt constituents and seasalt modification at Syowa Station, Antarctica, Tellus, 57B, 230246, 2005.

Hara, K., Iwasaka, Y., Wada, M., Ihara, T., Shiba, H., Osada, K., and Yamanouchi, T.: Aerosol constituents and their spatial distribution in the free troposphere of coastal Antarctic regions, J. Geophys. Res., 111, D15216, doi:10.1029/2005JD006591, 2006.

Hara, K., Osada, K., Yabuki1, M., Hashida, G., Yamanouchi, T., Hayashi, M., Shiobara, M., Nishita-Hara, C., and Wada, M.: Haze episodes at Syowa Station, coastal Antarctica: Where did they come from?, J. Geophys. Res., 115, D14205, doi:10.1029/2009JD012582, 2010a.

Hara, K., Osada, K., Yabuki, M., Hayashi, M., Yamanouchi, T., Shiobara, M., and Wada, M.: Black carbon at the coastal Antarctic station (Syowa): Seasonal variation and Transport processes, Antarctic Rec., 54, 562-592, 2010b (in Japanese with English abstract).

Hara, K., Matsuki, A., Yamagata, S., Iwasaka, Y., Yamanouchi, T. and Herber, A.: Aerosols in Arctic troposphere in spring and summer: spatial features of aerosol constituents and their mixing states, Antarctic Rec., 54, 845-867, 2010c (in Japanese with English abstract).

Hara, K., Osada, K., Nishita-Hara, C., Yabuki, M., Hayashi, M., Yamanouchi, T., Wada, M., and Shiobara, M.: Seasonal features of ultra-fine particle volatility in coastal Antarctic troposphere, Atmos. Chem. Phys., 11, 9803-9812, doi:10.5194/acp-11-98032011, 2011a.

Hara, K., Osada, K., Nishita-Hara, C., and Yamanouchi, T.: Seasonal variations and vertical features of aerosol particles in the Antarctic troposphere, Atmos. Chem. Phys., 11, 5471-5484, doi:10.5194/acp-11-5471-2011, 2011 b.

Hara, K., Osada, K., Yabuki, M., and Yamanouchi, T.: Seasonal variation of fractionated sea-salt particles on the Antarctic coast, Geophys. Res. Lett., 39, L18801, doi:10.1029/2012GL052761, 2012.

Hayashi, M.: Size distribution of aerosol in the stratosphere and troposphere observed with air-borne optical particle counter, Earozoru Kenkyu, 16, 118-124, 2001 (in Japanese).

Iizuka, Y., Hondoh, T., and Fujii, Y.: $\mathrm{Na}_{2} \mathrm{SO}_{4}$ and $\mathrm{MgSO}_{4}$ salts during the Holocene period derived by high-resolution depth analysis of a Dome Fuji ice core, J. Glaciol., 52, 58-64, 2006.

Iizuka, Y., Tsuchimoto, A., Hoshina, Y., Sakurai, T., Hansson, M., Karlin, T., Fujita, K., Nakazawa, F., Motoyama, H., and Fujita, S.: The rates of sea salt sulfatization in the atmosphere and surface snow of inland Antarctica, J. Geophys. Res., 117, D04308, doi:10.1029/2011JD016378, 2012.

Ishizaka, Y., Hobbs, P. V., and Radke, L. F.: Arctic hazes in summer over Greenland and the north American Arctic: II. Nature and concentrations of accumulation-mode and giant particles, J. Atmos. Chem., 9, 149-159, 1989.

Ito, T., Morita, Y., and Iwasaka, Y.: Balloon observation of aerosols in the Antarctic troposphere and stratosphere, Tellus, 38B, 214222, 1986.

Ito, T.: Antarctic Submicron Aerosols and Long-Range Transport of Pollutants, Ambio, 18, 34-41, 1989.
Iwasaka, Y., Okada, K., and Ono A.: Individual aerosol particles in the Antarctic upper troposphere, Mem. Natl. Inst. Polar Res. Spec. Issue, 39, 17-29, 1985.

Jourdain, B. and Legrand, M.: Seasonal variations of atmospheric dimethylsulfide, dimethylsulfoxide, sulfur dioxide, methanesulfonate, and non-sea-salt sulfate aerosols at Dumont d'Urville (coastal Antarctica) (December 1998 to July 1999), J. Geophys. Res., 106, 14391-14408, 2001.

Jourdain, B., Preunkert, S., Cerri, O., Castebrunet, H., Udisti, R., and Legrand, M.: Year-round record of size segregated aerosol composition in central Antarctica (Concordia Station): Implications for the degree of fractionation of sea-salt particles, J. Geophys. Res., 113, D14308, doi:10.1029/2007JD009584, 2008.

Keene, W. C., Maring, H., Maben, J. R., Kieber, D. J., Pszenny, A. A. P., Dahl, E. E., Izaguirre, M. A., Davis, A. J., Long, M. S., Zhou, X., Smoydzin, L., and Sander R.: Chemical and physical characteristics of nascent aerosols produced by bursting bubbles at a model air-sea interface, J. Geophys. Res., 112, D21202, doi:10.1029/2007JD008464, 2007.

Kerminen, V. M., Teinilä, K., and Hillamo, R.: Chemistry of sea-salt particles in the summer Antarctic atmosphere, Atmos. Environ., 34, 2817-2825, 2000.

Kizu, N., Hayashi, M., Yamanouchi, T., Iwasaka, Y., and Watanabe, M.: Seasonal and annual variations of aerosol concentrations in the troposphere and stratosphere over Syowa Station observed using a balloon-borne optical particle counter, Antarctic Rec., 54, 760-778, 2010.

Koch, D. and Hansen, J.: Distant origins of Arctic black carbon: A Goddard Institute for Space Studies model experiment, J. Geophys. Res., 110, D04204, doi:10.1029/2004JD005296, 2005.

Koponen, I. K., Virkkula, A., Hillamo, R., Kerminen, V.-M., and Kulmala, M.: Number size distributions and concentrations of the continental summer aerosols in Queen Maud Land, Antarctica, J. Geophys. Res., 108, 4587, doi:10.1029/2003JD003614, 2003.

Laskin, A. and Cowin, J. P.: Automated single-particle SEM/EDX analysis of submicrometer particles down to $0.1 \mu \mathrm{m}$, Anal. Chem., 73, 1023-1029, 2001.

Laskin, A., Moffet, R. C., Gilles, M. K., Fast, J. D., Zaveri, R. A., Wang, B., Nigge, P., and Shutthanandan, J.: Tropospheric chemistry of internally mixed sea salt and organic particles: Surprising reactivity of $\mathrm{NaCl}$ with weak organic acids, J. Geophys. Res., 117, D15302, doi:10.1029/2012JD017743, 2012.

Legrand, M. and Mayewski, P.: Glaciochemistry of polar ice cores: A review, Rev. Geophys., 35, 219-243, doi:10.1029/96RG03527, 1997.

Legrand, M., Sciare, J., Jourdain, B., and Genthon, C.: Subdaily variations of atmospheric dimethylsulfide, dimethylsulfoxide, methanesulfonate, and non-sea-salt sulfate aerosols in the atmospheric boundary layer at Dumont d'Urville (coastal Antarctica) during summer, J. Geophys. Res., 106, 14409-14422, 2001.

Li, F., Ginoux, P., and Ramaswamy, V.: Transport of Patagonian dust to Antarctica, J. Geophys. Res., 115, D18217, doi:10.1029/2009JD012356, 2010.

Mamane, Y. and Gottlieb, J.: Nitrate formation on sea-salt and mineral particles - A single particle approach, Atmos. Environ., 26, 1763-1769, 1992.

Minikin, A., Legrand, M., Hall, J., Wagenbach, D., Kleefeld, C., Wolff, E., Pasteur, E., and Ducroz, F.: Sulfur-containing species (sulfate and methanesulfonate) in coastal Antarctic aerosol and 
precipitation, J. Geophys. Res., 103, 10975-10990, 1998.

Moore, J. K. and Abbott, M. R.: Surface chlorophyll concentrations in relation to the Antarctic Polar Front: seasonal and spatial patterns from satellite observations, J. Mar. Syst., 37, 69-86, 2002.

Mouri, H., Nagao, I., Okada, K., Koga, S., and Tanaka, H.: Individual-particle analyses of coastal Antarctic aerosols, Tellus, 51B, 603-611, 1999.

Ohno, H., Igarashi, M., and Hondoh, T.: Salt inclusions in polar ice core: Location and chemical form of water-soluble impurities, Earth Planet. Sci. Lett., 232, 171-178, 2005.

Okada, K., Wu, P. M., Tanaka, T., and Hotta, M.: A light balloonborne sampler collecting stratospheric aerosol particles for electron microscopy, J. Meteorol. Soc. Jpn., 75, 753-760, 1997.

Okada, K., Wu, P. M., Tanaka, T., and Hotta, M., A light balloonborne sampler collecting stratospheric aerosol particles for electron microscopy, J. Meteorol. Soc. Jpn., 75, 753-760, 1997. Okada, K., Ikegami, M., Zaizen, Y., Makino, Y., Jensen, J. B., and Gras, J. L.: The mixture state of individual aerosol particles in the 1997 Indonesian haze episode, J. Aerosol Sci., 32, 1269$1279,2001$.

Okada, K., Ikegami, M., Zaizen, Y., Tsutsumi, Y., Makino, Y., Jensen, J. B., and Gras, J. L.: Submicrometer sulfur-rich particles in the middle troposphere: Aircraft observations from Australia to Japan, Atmos. Res., 88, 185-198, 2008.

Osada, K., Hara, K., Wada, M., Yamanouchi, T., and Matsunaga, K.: Vertical distribution of atmospheric aerosol particles over Syowa Station, east Antarctica: Airborne observations from spring to summer in 2004, Polar Meteorol. Glaciol., 20, 16-27, 2006.

Piel, C., Weller, R., Huke, M., and Wagenbach, D.: Atmospheric methane sulfonate and non-sea-salt sulfate records at the European Project for Ice Coring in Antarctica (EPICA) deep-drilling site in Dronning Maud Land, Antarctica, J. Geophys. Res., 111, D03304, doi:10.1029/2005JD006213, 2006.

Pereira, K. C. D., Evangelista, H., Pereira, E. B., Simoes, J. C., Johnson, E., and Melo, L. R.: Transport of crustal microparticles from Chilean Patagonia to the Antarctic Peninsula by SEM-EDS analysis, Tellus, 56B, 262-275, doi:10.1111/j.16000889.2004.00105.x, 2004.

Preunkert, S., Jourdain, B., Legrand, M., Udisti, R., Becagli, S., and Cerri, O.: Seasonality of sulfur species (dimethylsulfide, sulfate, and methanesulfonate) in Antarctica: Inland versus coastal regions, J. Geophys. Res., 113, D15302, doi:10.1029/2008JD009937, 2008.

Rankin, A. M. and Wolff, E. W.: Aerosol Profiling Using a Tethered Balloon in Coastal Antarctica, J. Atmos. Ocean. Technol., 19, 1978-1985, 2002.

Rankin, A. M. and Wolff, E. W.: A year-long record of sizesegregated aerosol composition at Halley, Antarctica, J. Geophys. Res., 108(D24), 4775, doi:10.1029/2003JD003993, 2003.

Rankin, A. M., Auld, V., and Wolff, E. W.: Frost flowers as a source of fractionated sea salt aerosol in the polar regions, Geophys. Res. Lett., 27, 3469-3472, doi:10.1029/2000GL011771, 2000.

Rankin, A. M., Wolff, E. W., and Martin, S.: Frost flowers: Implications for tropospheric chemistry and ice core interpretation, J. Geophys. Res., 107, 4683, doi:10.1029/2002JD002492, 2002.

Read, K. A., Lewis, A. C., Bauguitte, S., Rankin, A. M., Salmon, R. A., Wolff, E. W., Saiz-Lopez, A., Bloss, W. J., Heard, D. E., Lee, J. D., and Plane, J. M. C.: DMS and MSA measurements in the Antarctic Boundary Layer: impact of
BrO on MSA production, Atmos. Chem. Phys., 8, 2985-2997, doi:10.5194/acp-8-2985-2008, 2008.

Sato, K. and Hirasawa, N.: Statistics of Antarctic surface meteorology based on hourly data in 1957-2007 at Syowa Station, Polar Sci., 1, 1-15, 2007.

Savoie, D. L., Prospero, J. M., Larsen, R. J., and Saltzman, E. S.: Nitrogen and sulfur species in aerosols at Mawson, Antarctica, and their relationship to natural radionuclides, J. Atmos. Chem., 14, 181-204, 1992.

Savoie, D. L., Prospero, J. M., Larsen, R. J., Huang, F., Izaguirre, M. A., Huang, T., Snowdon, T. H., Custals, L., and Sanderson, C. G.: Nitrogen and sulfur species in Antarctic aerosols at Mawson, Palmer Station, and Marsh (King George Island), J. Atmos. Chem., 17, 95-122, 1993.

Shaw, G. E.: Antarctic aerosols: A review, Rev. Geophys., 26(1), 89-112, doi:10.1029/RG026i001p00089, 1988.

Stohl, A. and Sodemann, H.: Characteristics of atmospheric transport into the Antarctic troposphere, J. Geophys. Res., 115, D02305, doi:10.1029/2009JD012536, 2010.

Suzuki, K., Yamanouchi, T., Hirasawa, N., and Yasunari, T.: Seasonal variations of air transport in the Antarctic and Atmospheric Circulation in 1997, Polar Meteorol. Glaciol., 18, 96-113, 2004.

Teinilä, K., Kerminen, V.-M., and Hillamo, R.: A study of sizesegregated aerosol chemistry in the Antarctic atmosphere, J. Geophys. Res., 105, 3893-3904, doi:10.1029/1999JD901033, 2000.

Udisti, R., Dayan, U., Becagli, S., Busetto, M., Frosini, D., Legrand, M., Lucarelli, F., Preunkert, S., Severi, M., Traversi, R., and Vitale, V.: Sea spray aerosol in central Antarctica. Present atmospheric behaviour and implications for paleoclimatic reconstructions, Atmos. Environ., 52, 109-120, 2012.

von Glasow, R. and Sander, R.: Variation of sea-salt aerosol pH with relative humidity, Geophys. Res. Lett., 28, 247-250, 2001.

Wada, M., Ihara, T., and Shiba, H.: Aerological and aerosol observations in the lower atmosphere using aircraft by the 41st Japanese Antarctic Research Expedition, 2000-2001, Antarctic Rec., 45, 257-278, 2001 (in Japanese with English abstract).

Wagenbach, D.: Coastal Antarctica: Atmospheric chemical composition and atmospheric transport, in Chemical Exchange Between the Atmosphere and Snow, edited by Wolff, E. W. and Bales, R. C., NATO ASI Ser., Ser., 1, 173-199, 1996.

Wagenbach, D., Ducroz, F., Mulvaney, R., Keck, L., Minikin, A., Legrand, M. J., Hall, S., and Wolff, E. W.: Sea-salt aerosol in coastal Antarctic regions, J. Geophys. Res., 103, 10961-10974, 1998.

Warneke, C., Froyd, K. D., Brioude, J., Bahreini, R., Brock, C. A., Cozic, J., de Gouw, J. A., Fahey, D. W., Ferrare, R., Holloway, J. S., Middlebrook, A. M., Miller, L., Montzka, S., Schwarz, J. P., Sodemann, H., Spackman, J. R., and Stohl, A.: An important contribution to springtime Arctic aerosol from biomass burning in Russia, Geophys. Res. Lett., 37, L01801, doi:10.1029/2009GL041816, 2010.

Weller, R. and Wagenbach, D.: Year-round chemical aerosol records in continental Antarctica obtained by automatic samplings, Tellus, 59B, 755-765, 2007.

Weller, R., Wöltjen, J., Piel, C., Resenberg, R., Wagenbach, D., König-Langlo, G., Kriews, M.: Seasonal variability of crustal and marine trace elements in the aerosol at Neumayer Station, Antarctica, Tellus, 60B, 742-752, doi:10.1111/j.1600- 
0889.2008.00372.x, 2008.

Weller, R., Minikin, A., Wagenbach, D., and Dreiling, V.: Characterization of the interannual, seasonal, and diurnal variations of condensation particle concentrations at Neumayer, Antarctica, Atmos. Chem. Phys., 11, 13243-13257, doi:10.5194/acp11-13243-2011, 2011.

Wilson, T. R.: Salinity and the major elements of sea-water, in Chemical Oceanography, edited by J. P. Riley and G. Skirrow, 365-413, Academic Press, San Diego, CA, USA, 1975.

Wolff, E. W., Fischer, H., Fundel, F., Ruth, U., Twarloh, B., Littot, G. C., Mulvaney, R., Röthlisberger, R., de Angelis, M., Boutron, C. F., Hansson, M., Jonsell, U., Hutterli, M. A., Lambert, F., Kaufmann, P., Stauffer, B., Stocker, T. F., Steffensen, J. P., Bigler, M., Siggaard-Andersen, M. L., Udisti, R., Becagli, S., Castellano, E., Severi, M., Wagenbach, D., Barbante, C., Gabrielli, P., and Gaspari, V.: Southern Ocean sea-ice extent, productivity and iron flux over the past eight glacial cycles, Nature, 440, 491-496, doi:10.1038/nature04614, 2006.
Wouters, L., Artaxo, P., and van Grieken, R.: Laser Microprobe Mass Analysis of Individual Antarctic Aerosol Particles, Int. J. Environ. Anal. Chem., 38, 427-438, 1990.

Yamanouchi, T., Wada, M., Fukatsu, T., Hayashi, M., Osada, K., Nagatani, M., Nakata, A., and Iwasaka, Y.: Airborne observation of water vapor and aerosols along Mizuho route, Antarctica, Polar Meteorol. Glaciol., 13, 22-37, 1999.

Yamato, M., Iwasaka, Y., Ono, A., and Yoshida, M.: On the sulfate particles in the submicron size range collected at Mizuho Station and in east Queen Maud Land, Antarctica, Polar Meteorol. Glaciol., 1, 82-90, 1987.

Yamazaki, K., Okada, K., and Iwasaka, Y.: Where Do Aerosol Particles in the Antarctic Upper Troposphere Come From? - A Case Study in January 1983, J. Meteor. Soc. Jpn., 67, 889-906, 1989. 